\title{
Farkındalık ve Kabullenme Psikoterapilerinin Temel Stratejileri ve İslam
}

\author{
Elif Kara \\ Dr., Hacı Bayram Veli Üniversitesi, Edebiyat Fakültesi, Sağlı Psikolojisi Anabilim Dalı \\ Dr., Hacı Bayram Veli University, Faculty of Letters, Department of Health Psychology \\ Ankara, Turkey \\ eliffkara28@gmail.com \\ orcid.org/0000-0003-1205-2943
}

\section{Main Strategies of Mindfulness and Acceptance Psychotherapies and Islam Abstract}

Living daily lives based on past sorrows and future worries, misleads people's minds to fail of recognition the value of present time. Negative experiences might cause the person to misinterpret and misjudge daily events and him/herself. For example, a person might think that he/she failed to succeed on the reason that he/she is a failor. The mindfulness and acceptance therapies, intent to ensure a person's life to be away from negative experiences and living life more attentive, caring, conscious and carefully. Hereby a person might choose for his/her a life suitable for the values that are important to him/her (graduating from the school, building a family, etc.).

Therapies based on mindfulness are considered as a member of cognitive behavioral therapies as they work on cognition and change behavior, and these therapies re-form a the metacognition. The concept of metacognition is the knowledge of the functioning of one's own thinking / cognitive processes. Avoiding negative emotions and thoughts is a way of negative coping. Such avoidance provides immediate relief, but prevents healing. The person can be healed only by recognition his/her dysfunctional negative way of thinking. Observing dissatisfied thoughts patiently, non-judging as good or bad, letting them go instead of taking them as a part of one's own personality, are steps of healing in mindfulness and acceptance based therapies. This state of emotion and thought can not be reached by self-enforcement. A life based on mindfulness requires long term practices. These practices are exercises such as breathtaking exercises, walking under rain, focusing on daily events, etc. that providing being at the moment. Therefore a mental management form improves that trains the mind and keeps it awake to live the life.

Acceptance and Commitment Therapies (ACT) on the other hand, help the person to implement one's values (building a good family, graduation from school, etc.) in a decisive manner. All components of mindfulness are implemented in this kind of therapy. The main point to distinguish those two, is the dominance of exercises to provide focusing on the moment in mindfulness therapy. ACT, on the other hand, more emphasizes the acceptance included by mindfulness.

The two therapies are complementary with one another. Both therapies aim to reduce dependence on the past and future. So the person can stay at the time he/she lives. Main strategies of both therapies are mutual including focusing at now, avoidance of judgement, observation, acceptance and cognitive defusion processes. Those processes need to be applied jointly. So the person gains the ability to stay in the moment. Herewith these skills, the mind will be ready for living in harmony with the

Intihal Taraması/Plagiarism Detection: Bu makale intihal taramasından geçirildi/This paper was checked for plagiarism Geliş/Received: 09 Ocak/January 2020 | Kabul/Accepted: 16 Mart/March 2020 | Yayın/Published: 20 Mart/March 2020 Atff/Cite as: Elif Kara, "Farkındalık ve Kabullenme Psikoterapilerinin Temel Stratejileri ve İslam = Main Strategies of Mindfulness and Acceptance Psychotherapies and Islam”, Eskiyeni 40 (Mart/March 2020), 377-406. https://doi.org/ 10.37697/eskiyeni.672921

Copyright () Anadolu Ilahiyat Akademisi/Anatolian Theological Academy, 06050, Ankara, Turkey |www.anilakademi.com CC BY-NC 4.0 | This paper is licensed under a Creative Commons Attribution-NonCommercial License 
ultimate goal of ACT. Through self conscious skills, a person can realize functional actions which are meaningful and suited his/her values.

Therapies based on mindfulness and acceptance are fed by the teachings of Buddhism, a spiritual tradition. In Buddhism, one's thoughts are assumed to have curative or diseased effects. So it is important to train thought according to Buddhism. Therefore it has been a source for mindfulness and acceptance therapies in the content of Buddhism, "concentration of the person on himself/herself, making sense of his/herself existence and purpose, managing and improving his/her thoughts and wishes". Sacred religions have concepts of mindfulness. Experiences of self-focus, mind and spirit, which are the purpose of mindfulness in religions, and these can provide a framework for mindfulness experiences. Because of these characteristics of believe, religious people have been prone to therapy with mindfulness practices. The important point here is not the way Buddhist practices are made, but the concepts that help cognitive/emotional recovery. For example, "acceptance", one of the elements that regulate the mind, is a psychological concept that provides healing. Although the arguments that ensure acceptance, first draw attention in Buddhism, there are many elements to be used to raise mindfulness, many daily practices can be used. The existence of many thoughts and practices that will ensure this in religions has brought the idea that religious clients can recover with their own concepts.

Here is an example of a daily practice that provides mindfulness and focus; "mindfulness with eating grapes". Daily practice can be walking, cooking etc. Therefore, instead of eating grapes, it may be another application within its own understanding that provides mindfulness for the Muslim client. In the field studies, it was emphasized that religious behaviors such as dhikr (chanting) and murakabah (feeling that God is observing) were used by religious counselors as they help one to focus on himself/herself to stay in the moment. Religions have more extensive content than many daily practices that are accepted for mindfulness practices.

As with mindfulness practices, it is also valid for ACT to benefit from religious concepts instead of daily life practices. Their own concepts, appropriate stories and metaphors can be used for Muslim clients to organize their cognition. For example, Mathnawi is widely used in psychotherapies. The metaphor of positive and negative thoughts considered as guest and temporary in the mind house, observing them, and letting them go as they should (without getting angry and judging but just trying to understand) were found to be very useful in ensuring the acceptance in the theoretical framework of mindfulness and acceptance therapies.

To summaries all above, we can claim that the effort shown by psycotherapies related to religion or sprituallity, does not have a meaning that psychology becoming more religious nor religious terms are transforming by being more relevant with the notions of psychology. Here, we are attemting to signify the diversity of many practices which attempt to build up mindfulness. Hereby it is possible to enrich therapies suitable with the cognitions of religious clients.

Mindfulness and acceptance therapies use common strategies in a therapeutic process; such as focusing on the present moment, non- judging, acceptance, observation and cognitive defusion so far. Althouugh the practices, stories and methaphors which are suitable for the steps of such therapies find their resources in Buddhism, it is not necessary to limit the practices and stories considering that the rich consepts of religions especially the rich and generous resources of Islam can easly be considered as a part of therapy processes. Islam offers a life full of values based on human happiness for every sphere of life, such as encouraging of working, hopefulness, being part of a worthful life, loyalty to family, and value of social life.

In this study, it is discussed that, with short sections of rich Islamic perspective, dhikr (chanting), murakabah (feeling that God is observing), worship, tawakkul (resignation), ridah (consent), towba (repentance) are practices and thoughts that will increase the mindfulness and acceptance of believers, so that it can be applied in the practices of mindfulness and acceptance therapy. Conceptual harmony was found between Islamic thought and mindfulness and acceptance-based therapies.

\section{Kevwords}

Psychology of Religion, Mindfulness, Acceptance and Commitment, Psychotherapy, Religion, Spirituality 


\section{Main Strategies of Mindfulness and Acceptance Psychotherapies and Islam}

Öz

Günlük hayat geçmiş üzüntüler ve geleceğe dair endişeler ile yaşandığında kişi içinde bulunduğu anın farkına varamaz. Olumsuz tecrübeler, kişinin yaşamındaki günlük olayları ve kendini olumsuz tanımlamasına, yargılanmasına yol açabilir. Örneğin; 'başarısız biri olduğum için bu sefer de başaramadım' gibi. Farkındalık ve kabullenme terapileri; kişinin hayatını olumsuz deneyimlerle anlamlandırmaktan uzaklaşmasını, hayatını bilinçli, dikkatli ve özenli yaşamasını sağlamayı amaçlamaktadır. Böylece kişi kendisi için önemli değerlerine uygun (örneğin okulunu bitirmek, bir aileye sahip olmak gibi değerler) bir yaşam seçebilir.

Farkındalık temelli terapiler, biliş üzerinde çalışarak davranış değişikliği sağladığı için bilişsel davranışçı terapi ailesinden kabul edilmektedir ve üst bilişi şekillendirmektedir. Üst biliş kavramı, kişinin kendi düşünme/bilişsel süreçlerinin işleyişini bilmesidir. Olumsuz duygu ve düşüncelerden kaçınma, olumsuz başa çıkma biçimidir. Bu tür kaçınmalar anlık rahatlamalar sağlar fakat iyileşmeyi engellemektedir. Birey ancak kendi işlevsiz olumsuz düşünme şeklini fark ederse iyileşebilir. Hoşnut olunmayan düşünceleri sabırla gözlemleme, iyi ya da kötü olarak yargılamama, onları kişiliğinin bir parçası olarak değerlendirmekten vazgeçerek, geçip gitmelerine izin vermesi, farkındalık ve kabullenme temelli terapilerde iyileşme adımlarıdır. Bu duygu ve düşünce durumu kendini zorlama ile elde edilememektedir. Farkındalığa dayalı bir yaşam, uzun vadeli uygulamalar gerektirir. Bu pratikler anda olmayı sağlayan nefes alma egzersizleri, yağmurda yürüme, günlük işlere odaklanma vb. egzersizlerdir. Böylece zihni eğiten ve zihni açık tutarak günlük hayatı yaşamayı sağlayan bir düşünce yönetme biçimi gelişir.

Kabullenme ve kararlılık terapisi (ACT) ise kişinin kendi değerlerini (iyi bir aileye sahip olmak, okulunu bitirmek vb.) kararlı bir şekilde yaşamasını amaçlar. Bu terapide farkındalığın tüm bileşenleri kullanılır. İki terapiyi ayıran nokta farkındalık terapisinde ana odaklanmayı sağlayan egzersizlerin daha baskın olmasıdır. ACT ise farkındalığın içerdiği kabulü daha çok vurgulamaktadır.

İki terapi birbirini tamamlayıcıdır. Her iki terapi geçmiş ve geleceğe bağımlılığı azaltmayı amaçlar. Böylece kişi içinde yaşadığı zamanda kalabilir. Her iki terapinin temel stratejileri ortaktır; şimdiye odaklanma, yargısızlık, gözlem, kabullenme ve bilişsel ayrışma süreçlerini içermektedir. Bu süreçler birlikte yaşanmalıdır. Böylece kişi anda kalma becerisi kazanır. Bu becerilerle zihin, ACT'nin nihai hedefi olan değerlerle uyumlu yaşama için hazır olacaktır. Kendindelik becerileri yardımıyla kişi kendi hayatı için anlamlı olan, değerlerine uygun işlevsel eylemleri gerçekleştirebilir.

Farkındalık ve kabullenme temelli terapiler manevi bir gelenek olan Budizm'in öğretilerinden beslenmektedir. Budizm'de kişinin düşüncelerinin iyileştirici veya hasta edici yönleri olduğu varsayılır. Bu nedenle budizme göre düşünceyi eğitmek önemlidir. Bu nedenle Budizm'in içeriğindeki “kişinin kendi üzerine yoğunlaşması, varlığını ve amacını anlamlandırması, düşüncelerimiz ve isteklerimizi yönetme" farkındalı ve kabullenme terapileri için kaynaklık etmiştir.

Kutsal dinlerin farkındalık üzerine kavramları vardır. Kendine olma, akıl ve ruha odaklanma deneyimlerinin içeriği, farkındalık deneyimleri için çerçeve sağlayabilir. İnancın bu özelliklerinden dolayı dindar insanlar farkındalık pratikleri ile terapi olmaya yatkın bulunmuştur. Burada önemli olan nokta, Budist uygulamaların yapılış şekilleri değil, sağladığı bilişsel/duygusal iyileşmeye yardımcı olan kavramlardır. Örneğin zihni düzenleyen unsurlardan biri olan "Kabullenme” iyileşme sağlayan psikolojik bir kavramdır. Kabullenmeyi sağlayan argümanlar ilk önce Budizm' de dikkati çekse de farkındalığı sağlamakta kullanılacak unsurlar oldukça fazladır, birçok gündelik uygulama kullanılabilir. Dinlerde bunu sağlayacak birçok düşünce ve uygulamanın oluşu dindar danışanların kendi kavramlarıyla iyileşebileceği düşüncesini getirmiştir.

Farkındalık ve odaklanma sağlayan günlük bir uygulama örneği şöyledir; “üzüm yeme ile farkındalk". Günlük pratikler yürüyüş, pişirmek vb. olabilir. Dolayısıyla bu üzüm yeme yerine, Müslüman danışan için farkındalık sağlayan, kendi anlayışı içinden başka bir uygulama olabilir. Alan çalısmala- 
rında zikir, murakabe gibi dini davranışlar da kişinin kendine odaklanmasını, anda kalmasını sağladığı için dindar danışanlar için kullanılabilir bulunmuştur. Dinler, farkındalık uygulamaları için kabul edilen birçok günlük uygulamadan daha geniş bir içeriğe sahiptir.

Farkındalık uygulamalarında olduğu gibi günlük hayattan uygulamalar yerine dini kavramlardan yararlanılabilmesi ACT için de geçerlidir. Bilişi düzenlemek için Müslüman danışanlar için kendi kavramları, uygun hikâye ve metaforlar kullanılabilir. Örneğin psikoterapilerde Mesnevîden çokça yararlanılmaktadır. Olumlu- olumsuz her türlü düşüncenin zihin evinde misafir gibi ve geçici olduğu, onları gözlemlemek, gerektiği gibi (öfkelenmeden, yargılamadan, sadece anlamaya çalışarak) ağırladıktan sonra gitmelerine izin vermek metaforu, farkındalık ve kabullenme terapilerinin kuramsal çatısındaki kabullenmeyi sağlamakta oldukça yararlı bulunmuş ve sıklıkla kullanılmıştır.

Özetlenecek olursa, psikoterapilerin maneviyat ve dinle ilgili çabaları dinin bire bir psikoloji kavramlarıyla uyumunun sağlanması ya da psikolojinin daha dini bir görünüm alması değildir. Dikkat çekilen nokta farkındalı̆̆ı sağlayabilen uygulamaların çok çeşitli olduğudur. Bundan dolayı dindar danışanların bilişlerine uygun dini uygulamalarla terapiler zenginleştirilmektedir.

Farkındalık ve kabullenme terapileri, terapötik süreçte ortak stratejiler kullanmaktadır. Bunlar şimdiye odaklanma, yargısızlık, kabullenme, gözlem ve bilişsel ayrışmadır. Bu adımlara uygun uygulama, hikâye ve metaforlar başlangıçta Budizm içinden kaynak bulsa da uygulama ve hikâye seçiminde sınır olmadığı için, dinlerin zengin kavramları ve bu çalışma için dikkate alınan İslam'ın zengin kaynakları terapi süreçlerine dahil edilebilir bulunmuştur. İslam değerlerle dolu bir yaşam sunmaktadır, İslam'da çalışmanın teşviki, ümitli olma, değerli bir yaşam içinde olma aileye bağlılık, sosyal yaşamın değeri gibi hayatın her alanı için insanın mutluluğunu esas alan değerler çok önemlidir.

$\mathrm{Bu}$ çalışmada zengin İslam düşüncesinden kısa kesitlerle zikir, murakabe ve ibadetin inançlı bireylerin farkındalığını artıracak uygulamalar olduğu ve farkındalık ve kabullenme terapisinin pratiklerinde uygulanabileceği tartışılmıştır. İslami düşünce ile farkındalık ve kabul temelli terapiler arasında kavramsal bir uyum bulunmuştur.

\section{Anahtar Kelimeler}

Din Psikolojisi, Farkındalık, Kabul ve Kararlılık, Psikoterapi, Din, Maneviyat

\section{Giriş}

Geçmişten gelen üzüntüler ve gelecek kaygısı sürekli zihinde dolaşırsa, kişi içinde bulunduğu anın farkına varamaz, yaşam geçmiş ve gelecek arasında kaybolur. Geçmiş olumsuz tecrübeler, kişinin yaşamındaki günlük olayları ve kendini olumsuz tanımlamasına, yargılanmasına yol açabilir. Örneğin; 'başarısız biri olduğum için bu sefer de başaramadım' gibi. Farkındalık ve kabullenme terapileri; kişinin kendini geçmiş olumsuz deneyimlerle yargılamak ve tanımlamak yerine olumsuz düşüncelerini fark etmesi, olumsuz yargılarda bulunmak yerine olayları olduğu gibi kabul etmesi ve olumsuz etiketleme, yargılamaların zihninden uzaklaşmasına izin vermesi sürecidir. ${ }^{1}$

Kabullenme ve kararlılık terapisi ${ }^{2}$ ise, kişinin kendi değerlerini (iyi bir aileye sahip olmak, okulunu bitirmek vb.) kararlı bir şekilde yaşamasını amaçlar. Bu terapide farkında-

1 Jon Kabat-Zinn, Full Catastrophe Living: Using the Wisdom of Your Body and Mind to Face Stress Pain, and Illness (New York: Bantam Dell Publishing, 1990).

2 Çalışmanın bundan sonrasında, kabul ve kararlılık terapisi için İngilizce'si "Acceptance and Commitment Therapy"den kısaltılan ACT ifadesi de kullanılacaktır. Türkiye'de yapılan çalışmalarda KKT şeklinde kullanım da mevcuttur. Ancak başka dillerde kullanımda ACT önerilmektedir. ACT kısaltmasının 
lı̆̆ın tüm bileşenleri kullanılır. İki terapiyi ayıran nokta farkındalık terapisinde içinde bulunulan ana odaklanmayı sağlayan nefes egzersizleri, metidasyon, benliğe yoğunlaşma gibi uygulamaların daha baskın olmasıdır. ${ }^{3}$ ACT ise farkındalığın içerdiği kabullenmeyi daha çok vurgulamaktadır. ${ }^{4}$ Bu nedenle Ögel'in (2015) deyimiyle "kabullenmesiz farkındalık olmaz, kabul ve kararlılık terapisinde ise farkındalığın tüm bileşenlerinden yararlanılmaktadır".

Her iki terapinin amacı olaylara yeni bir bakış açısı geliştirmek, geçmiş ya da geleceğe bağımlı kalmadan hayatın içine girmek ile ilgilidir. ${ }^{6}$ Her iki terapinin temel stratejileri ortaktır; şimdiye odaklanma, yargısızlık, gözlem, kabullenme ve bilişsel ayrışma süreçlerini içermektedir. İki terapi birbirini tamamlayıcıdır, farkındalıkla günlük yaşamla güçlü bir bağ oluşturulup, anda kalmak sağlandıktan sonra ACT için nihai hedef olan, değerlere uygun bir yaşamın yolu açılmaktadır.

Manevi/dini değerlerin terapi süreçlerine entegre edilmesi, katkı vermesi, ${ }^{8}$ uzun bir süredir devam etmektedir. Psikoloji bilimi inançlı danışanlar için kendi dini kavramlarının terapi sürecine dahil edilmesinin, terapiyi kolaylaştırdığını görmüş ve dini inançların sağladığı iç görü, kendini anlama, kabullenme gibi unsurların farkındalık deneyimleri için iyi bir çerçeve sağlayabileceği ${ }^{9}$ dikkat çekmiştir. Kişinin kendi manevi ve dinî öğretilerindeki unsurlar, farkındalık ve kabullenme terapilerinin metaforlarını zenginleştirmektedir. ${ }^{10}$

İngilizce okunuşu, Türkçe eylem- hareket anlamına geldiği için de tercih edilmektedir. Bk. Russ Harris, Kabul ve Kararllık Terapisi ACT’i Kolay Öğrenmek ìlkeler ve Ötesi İçin Hızlı Bir Başlangıç, çev. Hasan Turan Karatepe - K. Fatih Yavuz (Istanbul: Litera Yayıncılık, 2018).

3 Kültegin Ögel, Farkindallk Ayrımsama ve Kabullenme Temelli Terapiler (Ankara: HYB yayıncllı, 2. Basım, 2015), 50; Russ Harris, Kabul ve Kararlllk Terapisi ACT’i Kolay Öğrenmek illkeler ve Ötesi İçin Hızlı Bir Başlangıç.

4 Pelin Devrim Çatak - Kültegin Ögel, "Farkındalık Temelli Terapiler ve Terapötik Süreçler”, Klinik Psikiyatri 13 (2010), 70-71; Harris, ACT’i Kolay Öğrenmek, 18-19.

5 Harris, ACT'i Kolay Öğrenmek, 18-19.

Ögel, Farkindalk Ayrrmsama ve Kabullenme Temelli Terapiler.

Ögel, Farkindalı Ayrımsama ve Kabullenme Temelli Terapiler; Harris, ACT’i Kolay Öğrenmek.

Ögel, Farkindal k Ayrimsama ve Kabullenme Temelli Terapiler, 111-168.

8 Halil Ekşi (ed.), Psikoterapi ve Psikolojik Danışmada Maneviyat Kuramlar ve Uygulamalar (İstanbul: Kaknüs Yayınları, 2017).

9 Ian Percv. Mindfulnessin Counselling and Psychotherapy: Narratives from Practitionersin Bhutan and Australia (Bentley WA Australia: Curtin University, Thesis Doctor of Philosophy, 2017), 47; David Jacobs Gordon, A Critical History of Mindfulness-Based Psychology (Middletown, CT, United States: Wesleyan University, Artswith Departmental Honors in Psychology and the Science in Society Program, Degree of Bachelor Thesis, 2009), 75.

10 Rosemary D. Behrens - Jerry L. Terrill, “The Navigation Tools of Spiritual Mindfulness"; James D. Herbert - Evan, M. Forman, Acceptace and Mindfulness in Cognitive Behavior Theraphy Understanding and Applying (Hoboken, New Jersey, United States: John Wiley \& Sons, Inc. 2010), 174; Kelvin Mutter, "The Practice of Mindfulness in Spiritual Care", Psychotherapy: Cure of the Soul, ed. Thomas St. James O'Connor vd. (Waterloo, Canada: Waterloo Lutheran Seminary, 2014), 131-138; Asimina Lazaridou - Panagiotis Pentaris, "Mindfulness and Spirituality: Therapeutic Perspectives", Person-Centered \& Experiential Psychotherapies 15/3 (2016), 235-244; Kabat-Zinn, Full Catastrophe Living, 364; Gordon, A Critical History of MindfulnessBased Psychology, 45,76; Jason A. Nieuwsma, vd., ACT for Clergy and Pastoral Counselors: Using Acceptance and Commitment Therapy to Bridge Psychological and Spiritual Care (Oackland CA United States: New Harbinger Publications Inc., 2016); Justin Thomas, vd., "The rise of mindfulness and its resonance with the Islamic tradition", Mental Health, Religion \& Culture 20/10 (2018). 
Bu çalışmada Kabat-Zinn (1990) ${ }^{11}$ tarafından geliştirilen farkındalık süreçleri ve kabullenme ve kararlılık terapileri için Hayes $(2004)^{12}$ ACT adımları kullanılmıştır.

Her iki terapinin uygulamaları farklı olmakla birlikte, kavramsal temellerin genel içeriğinden, ortak yönlerinden bahsedilmiştir. Müslüman danışanların terapi sürecini daha etkili hale getirmesi amacıyla farkındalık ve kabullenmeyi sağlamaya yardımcı olacak dini kavramların, terapilerle genel uyumu ortaya konulmaya çalışılmıştır. Farkındalık-kabullenme terapilerinin ortak temel stratejileri olan, şimdiye odaklanma, yargısızlık, kabullenme, gözlem ve bilişsel ayrışma ve İslam dini içindeki bazı kavramlar olan rıza, kabullenme, tevekkül, tövbe, zikir, murakabe, müşahede, hayret gibi kavramların psikoterapi süreçlerine dâhil edilmesi ve uygulanabilirliği araştırılmıştır.

\section{Farkındalık Terapisi}

Geçmiş ve gelecekle ilgili olumsuz düşüncelerle zihni meşgul etmek, şu an içinde bulunulan yaşamı bilinçli bir şekilde yaşamaya engel olmaktadır. Bu da dalgın (mindlessness) olmak demektir. ${ }^{13}$ Farkındalık (mindfulness) hayatı bilinçli, dikkatli ve özenli yaşamaktır. ${ }^{14}$ Farkındalık ve kabullenme terapileri üst bilişi şekillendirmektedir. Üst biliş kavramı, kişinin kendi düşünme/bilişsel süreçlerinin işleyişi ile ilgili bilgi edinmesi ve bu sayede düşüncelerini izleyebilmesi ve yönetebilmesi becerisi olarak tanımlanmıştır. ${ }^{15}$ Kendisinin ne düşündüğünün farkında olan birey tekrarlayan işlevsiz olumsuz duygu ve düşüncelerini anlayabilecektir. ${ }^{16}$ Bu terapilerin işleyişinde olumsuz olayların zihinde bıraktığı izleri silmek değil, onlara bakış açısını değiştirmek yer almaktadır. Bakış açısı değiştiğinde iyileşme de beraberinde gelecektir. Bunun sağlanması için; kişinin kendi düşünme şeklini izleyebilmesi, olumsuz düşüncelerinin farkına varıp onların varlığını kabul etmesi, düşüncelerine biraz uzaktan bakması gerekmektedir. Kişinin hoşlanmadığı düşüncelerini sabırla gözlemlemesi, iyi ya da kötü olarak etiketlemeden görmesi, onları kişiliğinin bir parçası olarak değerlendirmekten vazgeçerek, geçip gitmelerine izin vermesi iyileşmeyi sağlayan adımlardır. ${ }^{17}$ Farkındalık temelli terapiler, bilişsel davranışçı terapi ailesinden kabul edilmektedir. Benzerlikleri biliş üzerinde çalışarak davranış değişikliği sağlamaktır. ${ }^{18}$ Örneğin Bilişsel davranışçı terapideki maruz bırakma (in vivo exposure) ile farkındalıktaki kişinin kendi düşüncelerini gözlemlemesinin benzer olumlu sonuçlara yol açtığı düşünülmektedir, ikisinde de olumsuz düşünceyle yüzleşmek vardır. Ayrıldığı noktalar ise kısaca; bilişsel davranışçı terapi müdahalesinde

11 Kabat - Zinn, Full Catastrophe Living.

12 Steven C. Hayes, "Acceptance and commitment therapy, relational frame theory, and the third wave of behavioral and cognitive therapies", Behavior Therapy 35/4 (2004), 639-665.

13 Ronald D. Siegel vd., "Mindfulness: What is it? Where did it come from?", Clinical handbook of mindfulness, ed. F. Didonna (Springer Science + Business, 2008), 6.

14 Siegel vd., "Mindfulness: What is it? Where did it come from?", 6.

15 John H. Flavell, Cognitive Development (Prentice-Hall,1985), 104.

16 Çatak-Ögel, “Farkındalık Temelli Terapiler ve Terapötik Süreçler”, 86-87; Rebecca Crane, Mindfulness-Based Cognitive Therapy: Distinctive Features (London and New York: Taylor \& Francis, 2.nd Edition, 2017), 154,155.

17 Kabat - Zinn, "Mindfulness-Based Interventions in Context: Past, Present, and Future", Clinical Psychology: Science and Practice 10 (2003), 17-31.

18 Herbert - Forman, Acceptace and Mindfulness in Cognitive Behavior Theraphy Understanding and Applying, 3; Ögel, Farkındalık Ayrımsama ve Kabullenme Temelli Terapiler, 49; Harris, ACT’i Kolay Öğrenmek, 80. 
olumsuz düşünce, işlevsiz olduğuna dair kanıtlarla ortadan kaldırılmaya çalışılırken, farkındalık ve kabullenme terapilerinde varlıkları kabul edilir, ancak kişiliğin bir parçası olmaktan çıarılıp gitmelerine izin verilir. ${ }^{19}$

Olumsuz duygu ve düşünceleri fark edip kabul etmek üstesinden gelmek için gereklidir. Bundan kaçınmak olumsuz bir başa çıkma biçimidir. Kaçınma anlık rahatlama sunsa da uzun vadede işe yaramayan, iyileşmeyi engelleyen kontrol çabasıdır. Farkındalıkla gelen iyileşme ise bir şeyleri değiştirmeye çalışmadan, olumsuz düşünceleri yargilamadan gözlemlemeyi, dikkat vermeyi, hoşa gitmeyen, üzüntü veren durumla direkt temas etmeyi ve kabul etmeyi gerektirir. ${ }^{20} \mathrm{Bu}$ duygu-düşünce durumu bireylerin kendini zorlaması ile elde edilememektedir. Farkındalık temelli bir yaşam uzun pratikler gerektirmektedir. Bu pratikler anda olmayı sağlayan nefes alma, yürüyüş vb. egzersizleri, sadece tek şey düşünerek, böylece odaklanma becerisini geliştirme ${ }^{21}$ gibi zihni eğiten, zihni açık tutarak günlük hayatı yaşamayı sağlayan düşünce yönetme çalışmalarıdır. Farkındalık uygulamalarının başlangıcının 7 önemli tutumsal unsuru vardır. Bu adımlar birbirinden bağımsız, hiyerarşik süreçler değildir, birbirine bağlı birbirini güçlendiren deneyimlerdir. ${ }^{22} \mathrm{Bu} 7$ süreçle üzüntü ve kaygılar etrafında yoğunlaşan, tekrar eden olumsuz düşüncelerden (ruminasyon) kurtulmayı öğrenmek, zihni tanımak, yaşantılara yeni bakış açısı kazanmak amaçlanmaktadır. ${ }^{23}$ Farkındalık ve kabullenme temelli terapilerde bu kavramlar kuramsal çerçevede ortak kullanılmaktadır. ${ }^{24}$

Farkındalık uygulamaları 7 temel tutumu içerir. "yargılamama, sabır, acemi zihni, güven, zorlamama kabul ve izin verme" bu maddelerin hepsi bir bütün halinde deneyimlenip, birbirini tamamladıklarında farkındalık sağlanmış olur. Olumsuz düşüncelerin zihinde belirdiği anda onları geçmişten edinilen bilgilerle "kötü" olarak yargılamadan, sabır, kaçınmama ve kabullenme olayı gözlemlemeyi sağlar ve böylece birey olumsuz olayın kendi kişiliğinin bir parçası olmadığını fark edip, geçip gitmesine izin verebilir. ${ }^{25}$ İç içe, birlikte olması beklenen bu süreçler şu şekildedir;

1.1. Yargılamama: Geçmiş yaşantılar karşılaştığımız olayları ve benliğimizi algılama üzerinde etkilidir. Yargılamama, kişinin kendi deneyimlerini “iyi, kötü, sevilebilir, ayıplanabilir... vb." olarak etiketlemeyi bırakması, olayları tarafsız bir şekilde olduğu

19 Çatak -Ögel, "Farkındalık Temelli Terapiler ve Terapötik Süreçler", 70-71, 85; Ögel, Farkındalkk Ayrımsama ve Kabullenme Temelli Terapiler, 59.

20 Kabat - Zinn, "Mindfulness-Based Interventions in Context: Past, Present, and Future", Clinical Psychology: Science and Practice 10 (2003), 12-14.

21 Ögel, Farkındallk Ayrımsama ve Kabullenme Temelli Terapiler, 68,181-182; Volkan Demir, "Bilinçli Farkındalık Temelli Bilișsel Terapi Programının Üniversite Öğrencilerinin Kaygı Düzeylerine Etkisi”, OPUS Uluslararası Toplum Araștrmaları Dergisi 7/12 (2017), 98-118.

22 Kabat - Zinn, Full Catastrophe Living, 31-32; a.mlf. "Mindfulness-Based Interventions in Context: Past, Present, and Future", Clinical Psychology: Science and Practice 10 (2003), 19-23; Mc Cartney, Counsellors' Perspectives on How Mindfulness Meditation Influences Counsellor Presence Within the Therapeutic Relationship, 71.

23 Ögel, Farkindalık Ayrımsama ve Kabullenme Temelli Terapiler, 59-60.

24 Ögel, Farkindallk Ayrımsama ve Kabullenme Temelli Terapiler.

25 Kabat - Zinn, Full Catastrophe Living, 29-30. 
gibi görmesi demektir. Yargılar bilişsel işlemleme hatalarıdır, ${ }^{26 *}$ kişi deneyimlerini olumsuz yorumlamaktadır. Bilişsel davranış̧̧ı terapinin üzerinde durduğu bilişsel işlemleme hataları, aslında farkında olmama halinin sonucudur. Kişinin kendini yargıladığını fark edebilmesi bilişsel ayrılmanın gerçekleşmesi için önemlidir. ${ }^{27}$ Farkındalık ve kabullenme terapisinin getirdiği yargısızlık ve kabullenme bilişsel çarpıtmaların oluşmasinı engeller. ${ }^{28}$

1.2. Sabır: Sabır kaygı verici olsa bile şimdiki andaki düşüncede kalabilmektir. ${ }^{29}$

1.3. Acemi, Yeni Başlayan Zihni: İçinde bulunulan zaman dilimini idrak edebilmek için her şeyi ilk kez görüyormuş gibi canlı bir şekilde görebilme, bunun için istekli olmak halidir. ${ }^{30}$ Bu şekilde, çocuk gibi gördüğü her şeye meraklı ve ilgili olabilmek kişinin kendi hayatının eşsiz olduğunu deneyimlemesine yardımcı olacaktır.

1.4. Güven: Bireyin kendini gözlemleyebileceğine, anlayabileceğine dair özgüveni olmalıdır. $^{31}$

1.5. Zorlamama: Farkındalık deneyimleri bir yere ulaşma, bir şey olmaya çalışma amacı taşımaz. İçinde bulunulan anda yaşanılanların gözlemlenmesi farkındalığın kendisidir. Zihindeki bir düşünceyi ya da bedendeki bir duyumu gözlemlemek yeterlidir. ${ }^{32}$ Böylece zamanla, anda yaşama ve günlük hayatın içinde olma becerisi kazanılabilir.

1.6. Kabul: Olumsuz olaylardan kaçınmadan varlıklarını kabul etmek farkındalık deneyiminde önemlidir. ${ }^{33}$ Yaşanılan olumsuz deneyimleri oldukları gibi karşılamak, olumsuz durumu kişiliğin parçası olarak algılamaktan vazgeçmek ve olumsuz sonucu her yaşantıya genellemeden sadece o olaya özgü değerlendirerek, kendinden ayırmak kabullenmenin bileşenleridir.

1.7. İzin Verme: Olumsuz düşünceyi olduğu gibi kabul etme, kişiliğin bir parçası olarak tanımlamaktan vazgeçme, geçip gitmesine izin verme ${ }^{34}$ kişinin günlük hayatını yaşa-

26 Ögel, Farkındalık Ayrımsama ve Kabullenme Temelli Terapiler, 126.

* Bilişsel işlemleme hataları: geniş bilgi için bk. Hakan Türkçapar, _Bilişsel Davranışçı Terapi: Temelleri ve Ötesi (İstanbul: Epsilon Yayınları, 2018).

27 Kabat-Zinn, Full Catastrophe Living, 33-34; a.mlf. "Mindfulness-Based Interventions in Context: Past, Present, and Future”, Clinical Psychology: Science and Practice 10 (2003), 23; Laura Lynn Mc Cartney, Counsellors' Perspectives on How Mindfulness Meditation Influences Counsellor Presence Within the Therapeutic Relationship (Calgary, Canada: University of Calgary, Department of Educational Psychology and Leadership Studies, Degree of Master of Arts, 2000), 77.

28 Ögel, Farkındalık Ayrımsama ve Kabullenme Temelli Terapiler, 54.

29 Kabat - Zinn, Full Catastrophe Living, 34-35. a.mlf. "Mindfulness-Based Interventions in Context: Past, Present, and Future", 24; Mc Cartney, Counsellors' Perspectives, 79.

30 Kabat - Zinn, Full Catastrophe Living, 35-36; a.mlf. "Mindfulness-Based Interventions in Context", 25; Mc Cartney, Counsellors' Perspectives, 82.

31 Kabat - Zinn, Full Catastrophe Living, 36-37; a.mlf. "Mindfulness-Based Interventions in Context”, 25; Mc Cartney, Counsellors' Perspectives, 82.

32 Kabat - Zinn, Full Catastrophe Living, 37-38; a.mlf. "Mindfulness-Based Interventions in Context", 26; Mc Cartney, Counsellors' Perspectives, 83.

33 Kabat - Zinn, Full Catastrophe Living, 38-39; a.mlf. "Mindfulness-Based Interventions in Context: Past, Present, and Future”, Clinical Psychology: Science and Practice 10 (2003), 27-28; Mc Cartney, Counsellors' Perspectives, 80.

34 Kabat - Zinn, Full Catastrophe Living, 39-40; a.mlf. "Mindfulness-Based Interventions in Context", 28-29; Mc Cartney, Counsellors' Perspectives, 84. 
masında yardımcı olur. Kabullenme, izin verme bilişsel ayrılma birbirini tamamlayan kavramlardır. Kişinin olumsuz olayla kendini tanımlamaktan vazgeçmesi, gitmesine izin vermesi bilişsel ayrılmayı tanımlamaktadır.

İç içe olması beklenen bu 7 süreci örnekle özetlersek; Kişiler yaşadıkları olumsuz olayları kendilerinin bir parçası olarak görüp kendilerini olumsuz olayla birleştirebilir ve kendilerini bu olumsuz yargılarla açıklayabilirler; "sınavlarım iyi gitmedi, ben zaten başarısız biriyim" gibi. Bu düşünce alışkanlığı yerine sınavdan düşük not alma durumunu yargılamadan "evet notlarım düşük" diyerek başarısızlık, düşük not almanın üzüntüsü gibi duyguları gözlemleyerek, kaçınmadan kabullenip "bu sefer iyi not almadım” demek gibi. Bu şeklide "başarısızım” yargısından kendini ayırıp ben başarısız değilim, çalıştığımda başarılı olabilirim” şeklinde düşünme ve böylece başarısızlık düşüncesini zihinden ve benlikten ayırma, gitmesine izin verme bu süreç için örnek olabilir. Kaygıya yol açan olumsuz otomatik düşüncelerin* farkında olunması, her türlü duygu, düşünceyi yargılamadan, bastırmadan kabullenmeyi ve benlikten ayrışarak gitmelerine izin vermeyi kolaylaştırmaktadır.

\section{Kabul ve Kararlilik Terapisi}

Geleneksel davranışçı terapilerin etkin bir şekilde kullanıldığ1 1950 ve 1960’lı yıllar bilişsel süreçleri dikkate alan terapi türlerinin gelişmesine önemli kaynak olmuşlardır. 1970' lerde ikinci dalga olarak tanımlanan bilişin davranış üzerindeki önemini dikkate alan bilişsel davranış̧̧ı terapi (BDT) işlevsiz düşünceleri kanıta dayalı bir şekilde ortadan kaldırarak yerine işlevsel olanı getirme yöntemiyle çalışmaktadır. ${ }^{35}$ Bilişsel davranışçı terapilerin verileriyle beslenen ve BDT ailesinden sayılan, 3. dalga bilişsel-davranışçı terapiler olarak adlandırılan terapilerden biri kabul ve kararlılık terapisidir. Modelin kurucusu Steve Hayes' tir. Kabul ve kararlılık terapisi, konuşulan dil ve bilişinin birbiriyle ilişkisine dikkat çekmiş, ilişkisel çerçeve kuramına dayalı bilişsel-davranışsal bir psikoterapi türü oluşturmuştur. Bu terapiye göre psikopatalojiye neden olan, bireyin acı deneyimleriyle kurduğu olumsuz ilişki biçimidir. Çünkü insan olayları açıklarken çevreyi de kullanmayı öğrenmektedir, olumsuz öğrenmelerle kurulan olumsuz bilişsel ilişkiler zamanla genellenir, düşünce biçimi haline gelir. Kabul ve kararlılık terapisi geçmiş olumsuz yaşantıyı olduğu gibi ve kaçınmadan kabul edip, olaylarla kurulan ilişkiyi, olaylara yüklenen anlamı değiştirmeyi amaçlayan, davranışın analiz edildiği, işlevsel yaklaşımlardır ${ }^{36}$

ACT biliş üzerinde, deneysel verilere dayanarak çalıştığı için BDT ailesindendir. Aradaki fark BDT işlevsel olmayan düşünceyi kanitlarla değiştirmeyi amaçlarken ${ }^{37}$ ACT bireyin kendisini rahatsız eden olumsuz düşünceyi kaçınmadan kabullenmesini, sonra

\footnotetext{
* Otomatik düşünce: Geniş bilgi için bk. Hakan Türkçapar, Bilişsel Davranış̧̧ı Terapi: Temelleri ve Ötesi (İstanbul: Epsilon Yayınları, 2018).

35 Judith S. Beck, BDT Temelleri ve Ötesi, çev. Muzaffer Şahin (İstanbul: Nobel Yayınları, 2016); Hakan Türkçapar, BDT Temel İlkeler ve Uygulama (İstanbul: Epsilon Yayınları, 2018).

36 Hayes, "Acceptance and commitment therapy, relational frame theory, and the third wave of behavioral and cognitive therapies”; Ögel, Farkındallk Ayrımsama ve Kabullenme Temelli Terapiler, 70-74; Harris, ACT’i Kolay Öğrenmek, 18-24.

37 Beck, BDT Temelleri ve Ötesi. Çev. Muzaffer Şahin; Türkçapar, BDT Temel İlkeler ve Uygulama; Ögel, Farkındalık Ayrımsama ve Kabullenme Temelli Terapiler; Harris, ACT’i Kolay Öğrenmek, çev. Hasan Turan Karatepe - K. Fatih Yavuz.
} 
onları geride bırakarak ayrışmayla iyileşmesini ve kişinin mutlu olacağına inandığı değerler çerçevesinde belirlediği davranışları kararlı bir şekilde devam ettirmesini hedefler. $^{38}$

ACT bu hedefini gerçekleştirmek için acı veren deneyimleri değil, kişinin o deneyimlere bakış açısını, olaylarla kurduğu bilişsel ilişkiyi, anlam ilişkisini değiştirecek böylece olumsuz etkiyi azaltacak bilişsel beceriler öğretmeyi hedeflemektedir. Buna kendindelik, daha genel kullanımıyla farkındalık (mindfulness) becerileri denmektedir. Bu beceriler kazanıldığında kişi tüm olumlu ve olumsuz duygu ve düşüncelerinin farkında olma, onları oldukları gibi kabul etme, böylece derin bir kendindelik duygusuyla eylemleri "şimdi ve burada" yapıyor olma becerisi kazanacaktır. Kendindelik becerileri yard1mıyla kişi kendi hayatı için anlamlı olan, değerlerine uygun işlevsel eylemleri gerçekleştirecektir. ${ }^{39}$

ACT' in nihai hedefi değerlere açık bir zihne ulaşmaktır. ${ }^{40}$ Değerlerin kararlı bir şekilde uygulanıp yaşama yön vermesi, olumsuz düşüncenin iyileşmesinde etkilidir. ${ }^{41}$ Örneğin "iyi bir öğrenci olmak" bunu isteyen kişi için anlamlıdır. Bu değere uygun yaşamak için, çalışmaya başlamak gibi kararlı bir adım atmak ve sürdürmek gerekir. Değerlere uygun yaşamı sağlayacak zihne ulaşmak için ACT 6 terapötik süreç içermektedir.

Bu süreçler, psikolojik esneklik kazanmayı sağlar. Psikolojik katılık, bireyin alışageldiği olumsuz düşünce ve yargı biçimleriyle düşünmesidir. Psikolojik/ bilişsel esneklik ise bireyin stres yaratan olumsuz koşullarda çözümler üretebilmesi, yeni durumlara uyum sağlayabilmesidir. ACT değerlere açık bir zihin kazandırmak için öncelikle öğrenilmiş olumsuz düşüncelerin bu 6 süreç ile geride bırakılmasını hedeflemektedir. Bu süreçler aşağ̀dadır;

2.1. Kabul: Farkındalık adımlarında olduğu gibi, kişinin olumsuz düşünce ve duygularını kaçınmadan, var olmasına izin vererek, olduğu gibi deneyimlemesidir.

2.2. Bilişsel Ayrışma: Olumsuz bilişsel süreçler kişinin davranışı üzerinde olumsuz işleve sahiptir, olayları geçmiş olumsuz deneyimlerle ilişkilendirmeye sebep olmaktadır. Bilişsel ayrışma ise kişinin olumsuz düşünce ile kendisi arasına mesafe koyması, olumsuz düşünce ile kendini yargılamaktan vazgeçerek, bu düşünceyi geride bırakabilme becerisidir.

2.3. An'a Odaklanma: Kişinin içinde bulunduğu anı deneyimleme becerisi kazanması, uzun vadede bilinçli ve kendi değerlerine uygun yaşayabilmesini sağlamaktadır.

2.4.Benliği Gözlemleyebilme: Kişinin kendi olumsuz duygu düşünce ve davranışlarının farkında olması becerisidir.

2.5. Değerler: ACT nihai amaç olarak kişinin kendi değerlerine uygun bir yaşama yönelmesini hedeflemektedir. Kişi yukardaki adımlarla işlevsiz davranışların bağlamından, olumsuz öğrenmeleri olaylarla ilişkilendirmekten uzaklaşma becerisi kazanıp, değerlere uygun, olumlu işlevleri olan yaşam için açık hale gelecektir.

38 Ögel, Farkındalık Ayrımsama ve Kabullenme Temelli Terapiler; Harris, ACT’i Kolay Öğrenmek, çev. Hasan Turan Karatepe - K. Fatih Yavuz.

39 Harris, ACT’i Kolay Öğrenmek, 18-19.

40 Fatih K. Yavuz, "Kabul ve Kararlılık Terapisi (ACT): Genel Bir Bakış”, Türkiye Klinikleri Dergisi Psikoterapinin Bugünü Özel Sayısı 8/2 (2015), 26.

41 Ögel, Farkındalık Ayrımsama ve Kabullenme Temelli Terapiler; Harris, ACT’i Kolay Öğrenmek, çev. Hasan Turan Karatepe - K. Fatih Yavuz. 
2.6. Kararlı Eylemler: Kişinin kendi değerlerine uygun davranışlar sergilemesidir. ACT için nihai hedef bu adımı sağlamaktır. ${ }^{42}$

\section{Farkındalık ve Kabullenme Terapilerinin Ayrıldı̆̆ı ve Ortak Yönleri}

Farkındalık terapisinde en çok kullanılan nefes egzersizleri, yürüyüş, günlük ev işleri gibi davranışlara odaklanma uygulamalarıyla; “yargılamama, sabırlı olma, acemi zihninde olma, kabul, izin verme, bunları gerçekleştirmek için kendini zorlamama” kendinde olma becerileri sağlanmaktadır. Böylece kişi kendi yaşamına karşı farkındalık kazanmaktadır, ACT modelinde bu farkındalık çalışmaları önemli bir yer tutar. ${ }^{43}$ Ayrıldığı yönler terapi süreçlerinin formüle edilişindedir, farkındalıkta uygulama daha fazla iken, kabul ve kararlılık terapisinde ise bilişsel süreçler üzerinde çalışma daha fazladır. ${ }^{44}$

ACT terapisinde farkındalığı sağlamak için farkındalık uygulamalarından yararlanılmaktadır. ${ }^{45}$ Farkındalık sağlamakta meditatif teknikler yüzlerce olabilir. ACT terapisinde de nefes en çok kullanılanıdır. Farkındalık sağlama ile ilgili bu tekniklere örnek olarak; akarsudaki yaprakları düşünme ve canlandırma, kendi ellerini izleme, kuru üzüm yeme ile farkındalık uygulamaları kullanılabilir bulunmuştur, Bunun yanı sıra gün boyu düşüncelere kapılmak yerine kişinin kendine odaklanmasını sağlayacak egzersizler önerilmektedir. Bu egzersizler çok çeşitli olabilir, örneğin çevredeki beş şeye odaklanmak, o an içinde bulunulan çevreden beş tür ses seçip onlara odaklanmak, ya da vücutla temas eden beş şeye odaklanmak gibi. Bu uygulamada bileğimizdeki saat, vücuda temas eden pantolon, yüzümüzde hissettiğimiz hava, yere değen ayaklarımız, sandalyeye yaslanan sırtımız gibi ${ }^{46}$ odaklanmak üzere birçok şey ACT terapisinde farkındalı̆̆ sağlamak üzere seçilebilir.

ACT ile farkındalığın kavramsal çerçevelerinde ortak terapötik süreçler vardır. Farkındalık adımları değerlere açı bir zihne ulaşmak için gereklidir. Bu süreçler; "şimdiye odaklanma, yargısızlık, kabullenme, gözlem ve bilişsel ayrışma" dır. ${ }^{47}$

\section{Farkındalık, Kabullenme ve Kararlılık Terapilerinin Manevi/Dini Değerlerle Zen- ginleştirilebilirliği}

Modern psikoloji insanın kendini manevi bir varlık olarak deneyimlendiğini gözlemlemiş, ${ }^{48}$ psikolojinin bilim haline gelme sürecinin başlarında, psikolojik iyi oluş haline dini manevi kaynakların katkıları gözden kaçmamıştır. James 1902 de yayınlanan "Dinsel Deneyimin Çeşitleri” adlı kitabında bilim ve dini dünyanın hazine evinin kilidini açmak için gerçek anahtarlar olarak görmüş ve ruh sağlığı için ikisinin de fayda sağlayan kaynaklar olacağını vurgulamıştır. ${ }^{49}$ Manevi/dini değerlerin inançlı danışanlarla çalışılan terapi süreçlerine entegre edilmesi uzun bir süredir uygulanmaktadır. ${ }^{50}$ Farkındalık

42 Ögel, Farkındalık Ayrımsama ve Kabullenme Temelli Terapiler, 83-88; Harris, ACT’i Kolay Öğrenmek,59-66.

43 Ögel, Farkındalık Ayrımsama ve Kabullenme Temelli Terapiler, 49-50; Harris, ACT’i Kolay Öğrenmek, 298-300.

44 Ögel, Farkındalık Ayrımsama ve Kabullenme Temelli Terapiler, 49-50.

45 Harris, ACT’i Kolay Öğrenmek, 141, 203-204.

${ }^{46}$ Harris, ACT’i Kolay Öğrenmek, 282-303.

47 Ögel, Farkındalı Ayrımsama ve Kabullenme Temelli Terapiler.

48 Ira Progoff, The Death and Rebirth of Psychology (New York: Mc Graw-Hill, 1969), 16, 24.

49 William James, The Varieties of Religious Experience a Study in Human Nature (PDF: eBooks@Adelaide, 2009), 95.

50 Halil Ekşi (ed.), Psikoterapi ve Psikolojik Danışmada Maneviyat Kuramlar ve Uygulamalar (İstanbul: Kaknüs Yayınlar1, 2017). 
süreçlerini geliştiren Kabat-Zinn dini geleneklerin iyi oluş haline desteğinin bir din propagandası olmadığını, dinlerin farkındalık deneyimini derinden yaşamayı sağladığını belirtmiştir. ${ }^{51}$

Farkındalık ve kabullenme temelli terapiler manevi bir gelenek olan Budizm'in öğretilerinden beslenmektedir. ${ }^{52}$ Budizm'in içeriğindeki "kişinin kendi üzerine yoğunlaşması, varlığını ve amacını anlamlandırması, düşüncelerimiz ve isteklerimizi yönetme, iyileştirme" farkındalık ve kabullenme terapileri için kaynaklık etmiştir. ${ }^{53}$ Farkındalık eğitimleri manevi becerilerin ön plana çıktığ $1^{54}$ süreçler olarak görülmüştür. Kutsal dinlerin farkındalık üzerine kavramları olduğu, ${ }^{55}$ dinlerde farkındalığın amacı olan kendine olma, akıl ve ruha odaklanma deneyimlerinin farkındalık içerdiğ ${ }^{56}$ birçok dinin farkındalık deneyimleri için çerçeve sağlayabileceğ ${ }^{57}{ }^{57}$ öörülmüştür. İnancın bu özelliklerinden dolayı dindar insanlar farkındalık pratikleri ile terapi olmaya yatkın bulunmuştur. ${ }^{58}$

Buradan anlaşılmaktadır ki, Budist uygulamalar, farkındalığı sağlamak üzere diğer dinlerin mensuplarına ve Müslümanlara sunulmuş değildir. Meditasyon teknik bir terimdir, "zihni düzenleme, huzurlu olma, bireyin kendi varlığına ulaşması" anlamlarına gelmektedir. ${ }^{59}$ Terapilerde önemli olan nokta, Budist uygulamaların yapılış şekilleri değil, sağladığı bilişsel/duygusal iyileşmedir. Örneğin zihni düzenleyen unsurlardan biri olan "Kabullenme" iyileşme sağlayan psikolojik bir kavramdır. Kabullenmeyi sağlayan argümanlar ilk önce Budizm’ de dikkati çekse de dinlerde bunu sağlayacak birçok düşünce ve uygulamanın oluşu dindar danışanların kendi kavramlarıyla iyileşebileceği düşüncesini getirmiştir. Farkındalık ve kabullenme terapileri bir dine, görüşe ait olmadığı ve süreçte kullanılacak hikâye ve metaforlar sınırlandırılmış olmadığı için, bu terapilerin terapötik iyileşme sağlayan kavramlarının (kabullenme, farkında olma, değerlere uygun yaşam) içeriği dindar danışanlar için dinlerden de elde edilebilir.

Burada amaç, dindar danışanlar için farkındalık terapisi söz konusu olduğunda kendi farkındalık sağlayan unsurlarını kullanmaktır. ${ }^{60}$ Bu doğrultuda İslam içindeki

51 Kabat - Zinn, Full Catastrophe Living, 436.

52 Kabat - Zinn, Full Catastrophe Living, 12.

53 Andrea D. Grabovac vd., "Mechanisms of Mindfulness: A Buddhist Psychological Model”, Mindfulness 2 (2011), 154-166.

54 Ögel, Farkındalık Ayrımsama ve Kabullenme Temelli Terapiler, 40-49. Harris, ACT’i Kolay Öğrenmek, 29.

55 Behrens - Terrill, “The Navigation Tools of Spiritual Mindfulness", 7; Herbert - Forman, Acceptace and Mindfulness in Cognitive Behavior Theraphy Understanding and Applying, 7; Mutter, "The Practice of Mindfulness in Spiritual Care", 7.

56 Lazaridou - Pentaris, "Mindfulness and Spirituality: Therapeutic Perspectives", 12.

57 Gordon, A Critical History of Mindfulness-Based Psychology, 75.

58 Mark Joseph Myers, Examinina the Relationship Between Mindfulness, Religious Coping Strategies, and Emotion Regulation (Lynchburg, VA, United States: Liberty University, A Dissertation Submitted in Partial Fulfillment of the Requirements for the Degree of Doctor of Philosophy, 2012), 72-73; Percy, Mindfulness in Counselling and Psychotherapy: Narratives from Practitioners in Bhutan and Australia, 49-119.

59 Halvor Eifring, Meditation in Judaism, Christianity and Islam: Technical Aspects of Devotional Practices (London: Bloomsbury Academic, 2018).

60 Percy, Mindfulness in Counselling and Psychotherapy: Narratives from Practitioners in Bhutan and Australia, 47. 
anlayışlar (inancın sağladığı iç görü, kendini anlama, yaşamı kabullenme) Müslüman danışanlar için farkındalığı sağlayacak uygulama çeşitlerine katkı verebilir. ${ }^{61}$ Bunun nedeni farkındalık ve kabullenme terapilerinin uygulamayı sınırlandıran Budizm içeriği gibi herhangi özel bir seçiminin olmayışıdır, farkındalığı sağlamakta kullanılacak unsurlar oldukça fazladır, birçok gündelik uygulama kullanılabilir. ${ }^{62}$ Bu noktadan yola çıkarak terapi sürecinde, danışanlara kendi anlayışlarına yakın olan uygulamalarla farkındalık sağlanabileceği ortaya konulmuştur. Farkındalığın ve odaklanmanın sağlandığı günlük bir uygulama örneği şöyledir; "üzüm yeme ile farkındalık" ${ }^{63}$ Dolayısıyla bu uygulama dindar danışan için farkındalık sağlayan, kendi anlayışı içinden bir çeşit olabilir. Alan çalışmalarında zikir, murakabe gibi dini davranışlar da kişinin kendine odaklanmasını, anda kalmasını sağladığı için dindar danışanlar için kullanılabilir bulunmuş, dinlerin yukarıda belirtilen bazı günlük uygulamalardan daha kapsamlı içerikleri olduğu, eşsiz zengin kaynaklar olduğu vurgulanmıştır. ${ }^{64}$

Farkındalık uygulamalarında olduğu gibi ACT sürecinde de "otobüsteki yolcular" metaforu yerine Müslüman danışanlar için kendi kavramları, uygun hikâye ve metaforlar kullanılabilir. ${ }^{65}$ Örneğin psikoterapilerde Mesnevî'den çokça yararlanılmıştır. Olumlu- olumsuz her türlü düşüncenin zihin evinde misafir gibi ve geçici olduğu, onları gözlemlemek, gerektiği gibi (öfkelenmeden, yargılamadan, anlamaya çalışarak) ağırladıktan sonra gitmelerine izin vermek ${ }^{66}$ metaforu, farkındalık ve kabullenme terapilerinin kuramsal çatısındaki kabullenmeyi sağlamakta oldukça yararlı bulunmuş ve sıklıkla kullanılmıştır. ${ }^{67}$

${ }^{61}$ Mark Joseph Myers, Examinina the Relationshin Between Mindfulness, Religious Coping Strategies, and Emotion Regulation (Lynchburg, VA, United States: Liberty University, A Dissertation Submitted in Partial Fulfillment of the Requirements for the Degree of Doctor of Philosophy, 2012), 72-73; Percy, Mindfulness in Counselling and Psychotherapy: Narratives from Practitioners in Bhutan and Australia, 49119; Behrens - Terrill, "The Navigation Tools of Spiritual Mindfulness", 7; Herbert - Forman, Acceptace and Mindfulness in Cognitive Behavior Theraphy Understanding and Applying, 7; Mutter, "The Practice of Mindfulness in Spiritual Care", 7; Thomas, "The rise of mindfulness and its resonance with the Islamic tradition", 11.

62 Harris, ACT'i Kolay Öğrenmek, 29.

63 Harris, ACT’i Kolay Öğrenmek, çev. Hasan Turan Karatepe - K. Fatih Yavuz.

64 Justin Parrot, "How to be a Mindful Muslim: An Exercise in Islamic Meditation", Yaqeen Institute for Islamic Research (2017), 1-24; Nazila Isgandarova, "Muraqaba as a Mindfulness-Based Therapy in Islamic Psychotherapy", Journal of Religion and Health August 58/4 (2019), 1146-1160; Saddigha Al-Ghalib vd., "A mindfulness based intervention to enhance university student wellbeing in Saudi Arabia" Middle East Journal of Positive Psychology 4/1 (2018), 142-157; Gagan Priya - Sanjay Kalra, "Mind-Body Interactions and Mindfulness Meditation in Diabetes", EurOPEAN EndocrinolOGY 14/1 (2018), 35-41; Seng Beng Tan vd., "Mindfulness: A New Paradigm of Psychosocial Care in the Palliative Care Setting in Southeast Asia", Ann Acad Med Singapore 46/9 (2017), 339-346.

65 Yavuz, "ACT and Islam", 139-149.

66 Abdülbaki Gölpınarl, Mevlânâ Celaleddin-i Rumi Mesnevi Şerhi (İstanbul: Başbakanlık Kültür Müsteşarlı̆̆ı Kültür Yayınları, 1974), 5/3670-3690b, 552-554.

67 G. Mirdal, "Mevlânâ Jalāl-ad-Dīn Rumi and Mindfulness", Journal of Religion and Health 51/4 (2012), 1202-1215; Mehmet Ak vd., "Mevlânâ Penceresinden Bilişsel Terapiler", Bilişsel Davranış̧ı Psikoterapi ve Araştırmalar Dergisi 3 (2014), 133-141; Ögel, Farkındallk Ayrımsama ve Kabullenme Temelli Terapiler. 
Özetlenecek olursa, psikoterapilerin maneviyat ve dinle ilgili çabaları dinin bire bir psikoloji kavramlarıyla uyumunun sağlanması ya da tam tersi değildir; Farkındalığı sağlayabilen uygulama çeşitliliğine dindar kişilerin kendi biliş, anlayış çerçevesinden kaynaklar sağlanabileceğidir. ${ }^{68}$

Bazı çalışma bulguları bu görüşleri doğrulamış, farkında olma ve manevi/dini inançlar arasında anlamlı bir ilişki olduğu görülmüştür. ${ }^{69}$ Manevi/dini içerikli farkındalık terapilerinin kişisel gelişime katkı, ${ }^{70}$ stresi, depresyonu ve tıbbi semptomları azaltma, ${ }^{71}$ madde bağımlılı̆̆ını iyileştirmede ${ }^{72}$ kanser hastalarında tedaviyi destekleme ${ }^{73}$ kanser hastlarında kabullenmeyi kolaylaştırma, ${ }^{74}$ evsiz gençlerin sorunlarını çözmede ${ }^{75}$ hamile kadınlar için

68 Kirk A. Bingaman, "The Art of Contemplative and Mindfulness Practice: Incorporating the Findings of Neuroscience into Pastoral Care and Counseling”, Pastoral Psychology 60 (2011); L.M. Miller, "The Experience of Prayer With a Sacred Object Within the Context of Significant Life Stress", Journal of Spirituality in Mental Health 13/4 (2011); J. Knabb, "Centering Prayer as an Alternative to Mindfulness-Based Cognitive Therapy for Depression Relapse Prevention”, Journal of Religion and Health 51/3 (2012).

69 L.Birnbaum - A. Birnbaum, "Mindful Social Work: From Theory to Practice", Journal of Religion \& Spirituality in Social Work: Social Thought 27/1-2 (2008); Steven F. Hick, Mindfulness and Social Work Practice (Chicago: Lyceum Books, 2009); Mary E. Connors, "Integrative Symptom-Focused Dynamic Psychotherapy", Clinical Social WorkJournal 20/1 (2010); A. Gockel, vd., "Mindfulness as Clinical Training: Student Perspectives on the Utility of Mindfulness Training in Fostering Clinical Intervention Skills", Journal of Religion \& Spirituality in Social Work: Social Thought 32/1 (2013); Lazaridou - Pentaris, "Mindfulness and Spirituality: Therapeutic Perspectives", 5, 11.

70 Luke Strongman, "Pastoral Care and Mindfulness: A Teaching Practice", Journal of Education and Training Studies 5/3 (2017), 122.

71 James Carmody vd., "Mindfulness, spirituality and health-related symptoms", Journal of Psychosomatic Research 64 (2008) 393-403; James Carmody vd., "An Empirical Study of the Mechanisms of Mindfulness in a Mindfulness-Based Stress Reduction Program”, Journal of Clinical Psychology 65/6 (2009), 613626; Kathryn Birnie vd., "Exploring Self-compassion and Empathy in the Context of Mindfulnessbased Stress Reduction (MBSR)", Stress and Health 26 (2010), 359-371; Parrot, "How to be a Mindful Muslim: An Exercise in Islamic Meditation; Manoj Sharma - Sarah E. Rush, "Mindfulness-Based Stress Reduction as a Stress Management Intervention for Healthy Individuals: A Systematic Review", Journal of Evidence-Based Complementary \& Alternative Medicine 19/4 (2014), 271-286; Jeffrey M. Greeson, "Decreased Symptoms of Depression After Mindfulness-Based Stress Reduction: Potential Moderating Effects of Religiosity, Spirituality, Trait Mindfulness, Sex, and Age", J Altern Complement Med 21/3 (2015), 166-174; Lazaridou - Pentaris, "Mindfulness and Spirituality: Therapeutic Perspectives"; Thomas, "The rise of mindfulness and its resonance with the Islamic tradition"; Isgandarova, "Muraqaba as a Mindfulness-Based Therapy in Islamic Psychotherapy".

72 Janis Leigh vd., "Spirituality, Mindfulness and Substance Abuse", September Addictive Behaviors 30/7 (2005), 1335-1341; Jonathan Appel - Dohee Kim-Appel, "Mindfulness: Implications for Substance Abuse and Addiction", Int J Ment Health Addiction 7 (2009), 506-512; Ryan C. Shorey vd., "Dispositional Mindfulness, Spirituality, and Substance Use in Predicting Depressive Symptoms in a Treatment-Seeking Sample", Journal of Clinical Psychology 71/4 (2015), 334-345.

73 Laura E. Labelle vd., "Does Self-Report Mindfulness Mediate the Effect of Mindfulness-Based Stress Reduction (MBSR) on Spirituality and Posttraumatic Growth in Cancer Patients?", The Journal of Positive Psychology 10/2 (2015), 153-166.

74 Maria Karekla - Marios Constantinou, "Religious Coping and Cancer: Proposing an Acceptance and Commitment Therapy Approach", Cognitive and Behavioral Practice 17/4 (2010), 371-381.

75 Linda Grabbe, "Spirituality Development for Homeless Youth: A Mindfulness Meditation Feasibility Pilot”, JChild Fam Stud 21 (2012), 925-937. 
kaygıyı azaltmada ${ }^{76}$ olumlu etkisi tespit edilmiştir. Dini uygulamalar borderline kişilik bozukluğuna özellikle iyi gelmektedir. ${ }^{77}$ Borderline kişilik bozukluğunda yoğun bir boşluk hissi vardır. ${ }^{78}$ Meditasyon borderline kişilik bozukluğunda boşluk hissini doldurmakta kendi varlığını fark etmesini sağlamakta, tedaviye yardımcı olmaktadır. ${ }^{79}$

BDT ve ACT için bilişsel süreçler ve davranış çok önemlidir, biliş ve davranış üzerinde çalışılır. Biliş ve davranışa verilen önem, İslam için de oldukça mühimdir. İslam düşüncesinde kendini bilme, neden var olduğunu anlama, hayatı anlamlandırma (tefekkür etme) ve değerlere uygun, mutlu, huzurlu yaşam önemlidir. İnsan aklından dolayı en kıymetli varlıktır, kendini bilmesi ve farkında olması ile başlayan bir süreçle yaşamı anlama, yaratıcıyı bilme yolunda ilerleyebilir. ${ }^{80}$ İslam dininde olumlu duygu ve düşünceye önem verilmiştir. İslam'da iyi şeyler düşünüp olumlu beklenti içinde olmak iyi şeylerle karşılaşmayı sağlar (örneğin "ben kulumun bana olan zannı yanındayım", yani iyi şeyler düşünürse iyiliklerle karşılaşır). Yine, Allah’a güvenmek huzurlu hissetmek, üzülmemek, kötü düşünceleri zihinden uzaklaștırmak ${ }^{82}$ birçok avette tavsiye edilmektedir.

İnsanın düsüncelerinin önemi tasavvufi kaynaklarda, örneğin Mevlânâ öğretilerinde yer almakta, düsüncenin insanın derin anlamı olduğu ifade edilmektedir ${ }^{83}$ Mesnevî birçok verde olumlu düsüncenin ișlevine dikkat cekmekte; "gül düșünen insanın qül bahçesine, diken düșünen insanın dikenliğe” dönüșeceği metaforu üzerinden havata bakıs açısının psikoloii üzerindeki olumlu/olumsuz etkileri anlatılmaktadır. ${ }^{84}$ Yine Mesnevî'de olumsuz düsünce ve endişeler gönül ormanında gezen yabani, tehlikeli hayvanlara benzetilmektedir. $^{85}$

Farkındalık deneyimleri öğrenerek değil, kişinin tecrübesiyle gerçekleşmektedir. ${ }^{86}$ Benzer şekilde tasavvufi yaşantı kişinin kendi içsel tecrübeleriyle ilerleyeceği, kendi özüne döndüren ${ }^{87}$ bir yolculuktur. Bu yolculuktaki kişiler; gönlü yoran aşırı istekler, hırs, öfke,

76 Elahe Aslami vd., "A Comparative Study of Mindfulness Effciency Based on Islamic-Spiritual Schemes and Group Cognitive Behavioral Therapv on Reduction of Anxiety and Depression in Pregnant Women", Int J Community Based Nurs Midwifery 5/2 (2017), 144-152.

77 Sina Hafizi, "Borderline Personality Disorder and Religion: A perspective from a Muslim country", Iran J Psychiatry 9/3 (2014), 137-141.

78 Ögel, Farkindallk Ayrımsama ve Kabullenme Temelli Terapiler, 212.

79 Vanessa H. Chafos - Peter Economou, "Beyond Borderline Personality Disorder: The Mindful Brain", Social Work Volume 59/4 (2014), 297-302.

80 Cavit Sunar, Tasavvuf Felsefesi veya Gerçek Felsefe (Ankara: Ankara Üniversitesi İlahiyat Fakültesi Yayınları, 1974), 36.

81 Ebû Abdillâh Muhammed b. İsmail el-Buhârî, et-Tecrî̉ü’s-sarîh, “Tevhit”, 35.

82 Kur'ân Yolu (Erișim 6 Nisan 2019), Yunus10/62; Kur'ân Yolu (Erișim 6 Nisan 2019), Fussilet 41/ 30; Kur'ân Yolu (Erișim 6 Nisan 2019), el-Zuhruf 43/68,69; Kur'ân Yolu (Erișim 6 Nisan 2019), el-Ahkaf 46/13; Kur'ân Yolu (Erişim 6 Nisan 2019), el-Araf 7/201; Kur'ân Yolu (Erişim 6 Nisan 2019), el-Kaf 50/16; Kur'ân Yolu (Erişim 6 Nisan 2019), el-Nas 114/4,5.

83 Mevlânâ Celaleddin-i Rumi, Fihi Ma Fih, Çev. Ahmed Avni Konuk (PDF: İz Yayıncıllk, 2006), 301.

84 Mevlânâ Celaleddin-i Rumi, Mesnevî (PDF), 2/278b.

85 Mevlânâ, Mesnevî, 1/2010b.

86 Kabat - Zinn, Full Catastrophe Living, 31-32; a.mlf. "Mindfulness-Based Interventions in Context: Past, Present, and Future", Clinical Psychology: Science and Practice 10 (2003), 19-20.

87 Ali Tenik - Vahit Göktaş, "Tasavvufi Düşüncede Zikir ve Zikirin Benlik İnşasına Etkisi”, Toplum Bilimleri $8 / 15(2014), 265$. 
cimrilik, kin, kıskançlık gibi bütün olumsuz duygu ve düşünceden arınan kişilerdir. Böylece kalpleri güzellikleri görmeye hazır hale gelir. ${ }^{88}$

Tasavvuf kavramları Müslümanın yaşantısına yön vermekte, kendini bilerek, farkında olarak yaşama, Allah'ın nimetlerini idrak etme, hayranlıkla âlemi izleyebilme, kabullenme, amaç edinme, geleceğe olumlu yönelmeyi konu edinmektedir. ${ }^{89}$ Tasavvufta "hal" olarak tanımlanan bilinç durumları derin yaşantılar içermektedir. Bu tecrübeler insanın kendisini tanımasıyla başlamakta, içinde yaşadığı dünyanın ve hakikatin kaynağına ulaşma sürecinde ilerlemesiyle devam etmektedir. Bu süreçte yaşanan haller, farkındal1ğın çok daha derin boyutlarını tanımlamakta ve 'hakikatle karşılaştığını sükûnet huzur ve varlığını tamamlandığını hissetme’ tecrübelerini içermektedir..$^{90}$ İnsan bu gelişimi kendi içsel kaynaklarıyla sağlayabilir. ${ }^{91}$

Bu özellikleriyle İslam'ın farkındalık ve kabullenme sağlayacak zikir, dua gibi birçok uygulamaya ve kabullenme sağlayacak birçok değere sahip olduğunu ve bu terapilere kaynak olabileceğini birçok çalışma tespit etmiştir. ${ }^{92}$ İslam kaynaklarındaki tefekkür, rıza, tevekkül, sabır gibi kavramlar bu iki terapinin kuramsal çerçevesine (inançlı bireylerle yürütüldüğü durumlarda) zenginlik katabilir. Müşahede, zikir, murakabe ve ibadetler inançlı bireylerin farkındalığını artıracak uygulamalara katkı sağlayabilir.

\section{Farkındalık ve Kabul Terapilerinin Temel Stratejileri ve Manevi/Dini Değerler}

İslam düşüncesinde geçmişin olumsuzluklarını tevekkül ya da tövbe ile çözümlemek, değerli olduğunu hatırlamak gelecekle ilgili ümitli olmak, içinde bulunulan zaman diliminin gerekliliklerini yaşamak esastır. İbadetler kişinin yaşamının kendinin, isteklerinin farkında olmasını sağlar, namaz kılan, dua eden kişi kendi benliğinin üzerinde yoğunlaşmaktadır, istekleriyle kendine bir yön vermektedir. Zikir ve murakabe müşahede gibi birçok tasavvufi uygulamada kişinin benliğine ve aşkın varlığa yönelme tecrübeleri vardır. Aşağıda farkındalık becerileri kazanma sağlaması açısından dini uygulama örnekleri tartışılmıştır.

\subsection{Farkındalık Becerileri Kazanmada Dini Uygulamalar}

5.1.1. İslam'da Anda Olmayı Sağlayan İbadetler: Dindar insanların ibadet uygulamaları farkındalığı sağlayan deneyimler olarak tespit edilmiş, farkındalık ile tedavi olmaya yatkın bulunmuşlardır. İbadet sürecinde ana odaklanılması kişinin farkındalık becerisini geliştirmesinde ve farkındalı̆̆ını artırmasında etkilidir ${ }^{93}$ İslamiyet'teki ibadet rutinleri ise anlık farkındalıklarla dolu bulunmuş, ${ }^{94}$ İslam dininin içinde bulunulan ana

88 Mevlânâ, Mesnevî, 1/3466-3495b.

89 Mustafa Merter, Psikolojinin Üçüncü Boyutu Nefs Psikolojisi ve Rüyaların Dili (İstanbul: Kaknüs Yayınları, 2014), 190.

90 Merter, Psikolojinin Üçüncü Boyutu Nefs Psikolojisi ve Rüyaların Dili, 189.

91 Mevlânâ, Mesnevî, 5/1066-1070b.

92 Mirdal, "Mevlânâ Jalāl-ad-Dīn Rumi and Mindfulness"; Ak, "Mevlânâ Penceresinden Bilişsel Terapiler"; Thomas, "The rise of mindfulness and its resonance with the Islamic tradition"; Yavuz, "ACT and Islam", 139-149; Isgandarova, "Muraqaba as a Mindfulness-Based Therapy in Islamic Psychotherapy".

93 Myers, Examining the Relationship Between Mindfulness, Religious Coping Strategies, and Emotion Regulation, 72-73.

94 Thomas, "The rise of mindfulness and its resonance with the Islamic tradition", 8-11; Myers, Examining the Relationship Between Mindfulness, Religious Coping Strategies, and Emotion Regulation, 78. 
zihnin yoğunlaşması pratikleriyle dolu olduğu, psikoterapiyi zenginleştirebileceği dikkat çekmiştir. ${ }^{95}$

İslam'da ibadetler esnasında zihinden başka düşünceleri uzaklaştırılması ve yapılan ibadete odaklanılması önemlidir. ${ }^{96}$ Farkında olmanın tersi "dikkatsizlik, yanılma, ihmal", "bir şeyin gerekliliği ortada iken bunun idrak edilememesi” "yeterince uyanık ve dikkatli davranılmamasından kaynaklanan yanılgı hali" anlamlarına gelen "gaflet"tir" Birçok ayette gafletten kurtulmaya ve dikkatli olmaya yönelik uyarılar yer almaktadır. ${ }^{98}$

İslam'da namaz, dua günlük ibadetlerinin yanı sıra "zikir, huşu, murakabe, müşahede, halvet” gibi deneyimler farkındalığı artırmaktadır. Müslüman danışanlar için bu haller farkındalık deneyimini kolaylaştırmakta ve zenginleştirmektedir. Yapılan çalışmalarda danışanın kendi pozitif değerlerinin kullanılması terapinin etkisini artırmakta olduğu, anksiyete ve depresyona karşı Müslüman danışanlara ilk önce murakabe teknikleri öğretilmesinin faydalı olduğu belirtilmiştir, ibadetler ve zikir, huşu, murakabe, müşahede, halvet gibi farkındalık deneyimi barındıran tecrübeler olumlu psikolojiye katkıları ve medidatif etkilerinden dolayı Müslüman danışanlar için tercih edilmiştir. ${ }^{99}$ Bu kavramların tanımına bakıldığında terapi sürecine katkı sağlayacağı anlaşılabilir:

"Halvet" kişinin huzur ve sükûnet içinde olabileceği şekilde yalnız kalarak, kendine dönüp manevi yönden olgunlaşmaya çaba sarf etmesidir. ${ }^{100}$ Dini literatürde "Allah'ı anmak ve unutmamak suretiyle gafletten ve nisyandan kurtuluş"101 anlamına gelen zikrin zihni ve bedeni rahatlatıcı etkileri vardır. ${ }^{102}$ Zikir farkındalı̆̆ın deneyimlenmesine yardımcı olur, odaklanma sağlar. ${ }^{103}$ Zikir, insanın benliğinin iyi olan özüne dönüşmesini sağlar, "Bir başka deyişle zikir kişiyi en temiz, en saf, en şeffaf, en Allah'a yakın ve Allah'la bir olma haline döndürüp, o anda kalmaya çağırır”. ${ }^{104}$ Zikir esnasında bilinç, Allah'ın hangi

95 Thomas, "The rise of mindfulness and its resonance with the Islamic tradition", 6.

96 Ebû Hâmid Muhammed el Gazzâlî, Bidayetü’l-hidâye, nşr. Veysel Akkaya (PDF: İstanbul: İnsan Yayınları İran Tasavvuf Serisi, 2003), 82-123.

97 Uludağ, “Gaflet”, Türkiye Diyanet Vakfi İslâm Ansiklopedisi (Erişim 18 Eylül 2019).

98 Kur'ân Yolu (Erişim 6 Nisan 2019), Yâsîn 36/6; Kur'ân Yolu (Erişim 6 Nisan 2019), Meryem 19/39; Kur'ân Yolu (Erişim 6 Nisan 2019), Kaf 50/22.

99 Arthur Saniotis, "Understanding Mind/Body Medicine from Muslim Religious Practices of Salat and Dhikr", Journal of Religion and Health 57/3 (2018); Parrot, "How to be a Mindful Muslim: An Exercise in Islamic Meditation"; Thomas, "The rise of mindfulness and its resonance with the Islamic tradition"; Aslami, "A Comparative Study of Mindfulness Effciency Based on Islamic-Spiritual Schemes and Group Cognitive Behavioral Therapy on Reduction of Anxiety and Depression in Pregnant Women"; S.H. S. Omar vd., "Techniques of Practicing Muraqaba by Sufis in Malay Archipelago", International Journal of Academic Research in Business and Social Sciences 7/5 (2017); Isgandarova, "Muraqaba as a Mindfulness-Based Therapy in Islamic Psychotherapy"; Hafizi, "Borderline Personality Disorder and Religion: A perspective from a Muslim country"; Chafos-Economou, "Beyond Borderline Personality Disorder: The Mindful Brain"; Eifring, Meditation in Judaism, Christianity and Islam: Technical Aspects of Devotional Practices.

100 Robert Frager, Kalp, Nefs ve Ruh, çev. İbrahim Kapaklıkaya (İstanbul: Gelenek Yayınları, 2003), 159; Michaela-Özelsel, Halvette Kırk Gün,9; Hüseyin Peker, Din Psikolojisi (İstanbul: Çamlıca Yayınları, 2011), 191.

101 Reşat Öngören, “Zikir”, Türkiye Diyanet Vakfi İslâm Ansiklopedisi (Erişim 18 Eylül 2019).

102 Behlül Tokur, Stres-Dindarlk İlişkisi Üzerine Bir Araştırma (Erzurum: Atatürk Üniversitesi, Sosyal Bilimler Enstitüsü, Doktora Tezi, 2011), 212; Michaela-Özelsel, Halvette Kırk Gün,179-184; Saniotis, “Understanding Mind/Body Medicine from Muslim Religious Practices of Salat and Dhikr".

103 Kayıklık, Tasavvuf Psikolojisi, 174.

104 Tenik - Göktaş, “Tasavvufi Düşüncede Zikir ve Zikirin Benlik İnşasına Etkisi”, 280. 
sıfatını zikrediyorsa o anlamayoğunlaşır. ${ }^{105}$ Örneğin "el-vekil: tevekkül edenlerin işlerini neticeye ulaştıran" sıfatını tekrarlayan sakinleşir, huzur hisseder. Murakabe, müşahede ve huşu halleri kendini ve çevresini derinden hissetme ve algılama sağlar. "Murakabe" hissinde kişi Allah'ınkendisini gözetlediğini ve yanında olduğunu deneyimler. ${ }^{106}$ "Müşahede" ile kendini ve âlemi, Allah'ın yarattıklarını gözlemler. ${ }^{107}$ "Huşu" ise Allah'ın huzurunda olduğu bilincini her antaşımak, sükûnetle ve tevazu ile hareket etmek, ${ }^{108}$ tüm varlı̆̆ımızla bir manada donup kalmak ${ }^{109}$ anlamlarına gelmektedir. Tüm bu uygulamalar kişinin kendini fark etme, kendini içinde bulunduğu dünya ile birlikte değerlendirme anlayışını geliştirmek içindir. Zikir, murakabe, müşahede ve huşu deneyimlerindeki kendine odaklanma, sükûnetle kendi düşüncelerini izleme, kâinatın yaratıcısı ile bağlantıda olduğu hissini yakalama ya da yakalamaya çalışma hali, iyiye güzele hakikate yaklaşma duygu ve düşüncesiyle olumlu bir zihne ulaşmada ve dikkat regülasyonu sağlamada önemlidir.

İslam düşüncesindeki "hayret ve hayranlık" kavramları, farkındalık kavramlarından "acemi bir zihinde olma" halini anlamayı inançlı danışanlar için kolaylaştırabilir. Tasavvuftaki "hayret ve hayranlık" ile farkındalık terapisindeki acemi zihninde olma benzer bir şekilde hayatı zengin bir şekilde algılamayı sağlamayı amaçlamaktadır. Hayret etmek, kendinden başlayarak dünyayı fark etme ve hayatı daha anlamlı, daha hayranlık duyarak yaşama yeteneğ ${ }^{110}$ ve Allah'ın yarattıklarına sevinçle karışık bir hayranlık, ibret alma ${ }^{111}$ şeklinde tanımlanmıştır.

Kur'an içinde bulunduğumuz her anın yeni bir an olduğuna; “...0, her an yaratma halindedir" ${ }^{\prime 12}$ ayeti ile işaret eder. Dünyadaki güzelliklere bakmak, hayret ve ibretle bakmakla ilgili ayetler ${ }^{113}$ oldukça fazladır. Buna bir örnek de Hz. İbrahim'in inanmasına rağmen kuşların nasıl yeniden dirildiğini görmek istemesi ${ }^{114}$ olabilir, bu istek kâinatın işleyişine duyulan merak, hayret ve hayranlıkla açıklanabilir. Her an benliğinin ve çevresinin, dünyanın, kâinatın farkında olmak ve hayranlıkla, hayretle bakmak, bilinçli olmak tasavvufi bir kavram olarak kullanılan "hayranlık, hayret" kavramlarılla anlam kazanmaktadır.

İslami kavramlar içinde yeri olan hayret ve hayranlık, farkındalık ve kabullenme terapilerinde çokça yararlanılan Mesnevî'de sıklıkla sunulmaktadır. ${ }^{115}$ Anda olma, farkındalıkla ilgili Mesnevî den en çok aktarılan ise her anın yeni bir an olduğunu hayret, hayranlık heyecan ve farkındalıkla açıklayan; "Dünya ırmağın suyu gibidir. Hep aynı gibi görünür. Fakat yeniden yeniye akar gider, Gelir, akar; bu nereden geliyor" ${ }^{116}$ beyitleridir.

\footnotetext{
105 Arabî, Fütühat-ı Mekkiye 91.

106 Kuşeyrî, er-Risaletül-Kuşeyrîyye, 266; Uludağ, "Murakabe”, Türkiye Diyanet Vakfi İslâm Ansiklopedisi (Erişim 18 Eylül 2019).

107 Merter, Psikolojinin Üçüncü Boyutu Nefs Psikolojisi ve Rüyaların Dili, 190; Sayın, TasavvufTerapisi; Uludağ, "Tevekkül”, Türkiye Diyanet Vakfi İslâm Ansiklopedisi (Erişim 18 Eylül 2019).

108 Mehmet Şener, “Huşû̀", Türkiye Diyanet Vakfi İslâm Ansiklopedisi (Erişim 18 Eylül 2019).

109 Merter, Psikolojinin Üçüncü Boyutu Nefs Psikolojisi ve Rüyaların Dili, 231.

110 Merter, Psikolojinin Üçüncü Boyutu Nefs Psikolojisi ve Rüyaların Dili, 283.

111 Feridüddin Attar, Mantıku't Tayr, çev. Abdülbaki Gölpınarlı (İstanbul: Meb Yayınları, 2001).

112 el-Rahman 55/29.

113 Kur'ân Yolu (Erișim 6 Nisan 2019), el-Rum 30/22; el-Bakara 2/164.

114 el-Bakara 2/260.

115 Mevlânâ, Mesnevî, 1/312-313b, 4/ 3750-3755b.

116 Mevlânâ, Mesnevî,1/218b.
} 
İslam kaynaklarından sunulan sınırlı kesit göstermektedir ki, farkındalık becerileri geliştirmek için İslam kaynakları kullanılabilir.

\subsection{Kabullenme Adımları İçin Dini Uygulamalar}

İnanç sistemleri farklı yöntemlerle bu hedeflere ulaşmayı amaçlar. ${ }^{117}$ Kişinin kendini ve kâinatı tanıması, anlamaya çalışması sürecini tanımlamada Budizm için samatha; konstrasyon veya sükûnet kullanılmaktadır. ${ }^{118}$ Benzer şekilde İslam inancındaki tefekkür kavramı derin düşünce, kendini ve âlemi düşünme, kalple görme"119 anlamlarında kullanılmaktadır. Daha önce değinildiği üzere bireyin iç dünyasına yolculuk farkındalık terapisinin temellerini aldığı Budizm'de yer aldığı gibi İslam düşüncesinde de yer almaktadır ve bunun psikoterapi için önemi, dindar danışanların kendi kaynaklarındaki terapi değeri taşıyan uygulamaların, kavramların, hikayelerin veya metaforların kullanılabilir olmasıdır.

Kabullenme ve kararlılık terapilerinde sorunların çözümüne yönelik farkındalık becerileri "şimdiki ana odaklanma (bu adımda kendindelik farkındalık becerileri olan güven, acemi zihni, zorlama, sabır boyutları kazanılır, bu boyutlar zaten odaklanmayı sağlamak, zihni deneyimlere açmak içindir, önceki konu başlığınsa yukarda verilmiştir) yargısızlık, kabullenme, gözlem ve ayrışma" dır. ${ }^{120}$ Bu süreçlerin manevi/dini kavramlarla zenginleştirilmesine yönelik değerlendirme örneği aşağıdadır.

5.2.1. Yaşantısal Kaçınmanın Çözümlenmesi İçin Kabullenmenin Gerekliliği: Olumsuz yaşam deneyimlerini düşünmek üzücü, acı vericidir. Bu düşüncelerden kaçınmak olumsuz bir başa çıma yöntemidir, kaçınmak kontrol etmenin olumsuz bir biçimidir. ${ }^{121}$ İstenmeyen duygularımızı korkularımızı kontrol etme çabasını bırakmak ve oldukları gibi kabul etmek önemlidir. ${ }^{122}$ Kabullenme ise kaçınmak yerine onlara (acı ve üzüntü, kaygı vb. veren deneyimlere) zihinde yer açmaktır orada olmalarına izin vermektir. Bu düşünceyi değiştirmek değil, olumsuz yaşam deneyimleriyle kurduğumuz ilişkiyi değiştirmektir. İlişki değişirse üzüntü de değişebilir. ${ }^{123}$ Bu süreç bilişsel davranışçı terapideki kaçınılan şeyi deneyimleme adımına benzemektedir. Kabullenme kişinin kendi deneyimlerine karşı adil olmasını şefkatli olmasını sağlar. ${ }^{124}$

İslam kaynaklarında sabır, rıza ve tevekkül birlikte değerlendirilmiştir. Sabırda olumsuz düşünce ve duygulardan kaçınmadan onları deneyimleme, tevekkülde olayların sonucu üzerinde hâkimiyet kurmaya çalışmak yerine elinden geleni yaparak sonucu Allah'a havale etme vardır. Rızada kontrol edilemeyen olumsuz olaylarla ilgili öfke, yenilgi hisleriyle dolmak yerine, olumsuz olayların varlıklarını kabul etmek ve umutla hayatı sürdürmek, iyi olmak için çaba sarf etmekten vazgeçmemek vardır. Tasavvufi kaynaklara

\footnotetext{
117 Eifring, Meditation in Judaism, Christianity and Islam: Technical Aspects of Devotional Practices.

118 Ögel, Farkındalık Ayrımsama ve Kabullenme Temelli Terapiler, 4.

119 İlhan Kutluer, “Düşünme”, Türkiye Diyanet Vakfi İslâm Ansiklopedisi (Erişim 18 Eylül 2019).

120 Ögel, Farkındalı Ayrımsama ve Kabullenme Temelli Terapiler, 111-168.

121 Ögel, Farkındalık Ayrımsama ve Kabullenme Temelli Terapiler, 28.

122 Ögel, Farkındalık Ayrımsama ve Kabullenme Temelli Terapiler, 38; Behrens - Terrill, “The Navigation Tools of Spiritual Mindfulness", 4; Ögel, Farkındalık Ayrımsama ve Kabullenme Temelli Terapiler, 83.

123 Ögel, Farkındalık Ayrımsama ve Kabullenme Temelli Terapiler, 83; Yavuz, "Kabul ve Kararlılık Terapisi (ACT): Genel Bir Bakış”, 24; Russ Harris, ACT’i Kolay Öğrenmek, çev. Hasan Turan Karatepe - K. Fatih Yavuz, 23.

124 Ögel, Farkındalı Ayrımsama ve Kabullenme Temelli Terapiler, 142.
} 
göre rahatsız eden düşünceleri zihninden çlkarmaya çalışmak güçlenmelerine sebep olur, huzursuz eden içsel konuşmalardan ve zihnimizi meşgul eden takıntılardan ancak onların varlıklarını kabul ederek ${ }^{125}$ ve onlar hakkında tevekkül ederek ${ }^{126}$ uzaklaşılabilir. İslam kaynaklarında sabır tevekkül ve rıza kişiyi olgunlaştıran, algısını derinleştiren süreçler olarak yorumlanmıştır ve İslam'da yaşam deneyimlerinin yıkıcı etkisine karşı sabır, rıza ve tevekkül önerilmiştir.

5.2.2. Sabır: Hapsetmek, tutmak, üzüntüyü geniş gönüllü metanetli bir şekilde karş1lamak $^{127}$ anlamlarına gelmektedir. Sabır, tevekkül ve rıza kavramları birbiriyle ilintili kavramlardır, Sabır Kur'ân ayetlerine olumsuz süreci kabullenerek yaşamak, yaşama karşı olumlu hislerini kaybetmemek gibi anlamlarla çokça geçmektedir. ${ }^{128}$ Alan yazında sabır, bireyin olumsuz süreci sakin ve metanetli bir şekilde yaşaması, kaçınmadan içinde olması, kabullenmesi, ${ }^{129}$ üzüntü veren deneyimlerle yüzleşme, sürecin içinde kalarak gözlemleme ${ }^{130}$ ümit dolu yaratıcı bekleyiş ${ }^{131}$ şeklinde yorumlanmaktadır. Sabrın bir yanı olumsuz deneyimleri kabul etmek, diğer yönü de iyi yaşama umudunu kaybetmemek, çaba sarf etmekten vazgeçmemek amaçlarına bağlı kalmak ${ }^{132}$ olarak tanımlanmaktadır.

İslam düşüncesinde sabır için birçok metafor kullanılmıştır, örneğin "sabır başa gelen acıları yüzü ekşitmeden yudumlamaktır", "sabır, dertsizlik ile arkadaşllk kurmak gibi, belâ ile de iyi arkadaşlk kurmaktır"133 gibi. Bu tanımda bilişsel davranış̧̧ı terapi ve farkındalıktaki yüzleşmeyi görebiliriz, terapi süreçlerinde olduğu gibi dini anlayıșta da sağlıklı bir psikolojiye ulaşabilmek için üzüntüyle yüzleşebilme, bu şekilde çözümleme vardır. Bu yönüyle bu anlayış terapileri zenginleştirici bir kaynak olabilir.

Yine Mesnevî'de sabır üzüntünün anahtarı ${ }^{134}$ hazineye (iç huzuruna) ulaştıran güç, ${ }^{135}$ acıya karşı etkili bir kimya, çare, deva ${ }^{136}$ tanımları yer almaktadır. Sabrın yaraya sürülen acı ve keskin ilaçlar gibi olduğu, yoksa yaranın kötü hale geleceğ $i^{137}$ gibi birçok

${ }^{125}$ Muhammed Ecmel, "Sûfi Ruhbilimi”, Sufi Psikolojisi, ed. Kemal Sayar (ìstanbul: Timaş Yayınları, 2008), 109.

${ }^{126}$ Mihriban Michaela-Özelsel, Halvette Kırk Gün, çev. Petek Budanur (ìstanbul: Kaknüs Yayınları, 2002), 60.

${ }^{127}$ Mehmet Demirci, “Kur'an-1 Kerim Işı̆̆ında Sabır Kavramı”, Sosyal Bilimler Enstitüsü Dergisi 12/20 (2002), 263; Abdülkerim Kuşeyrî,er-Risaletül-Kuşeyrîyye, çev. Ali Arslan (İstanbul: Hikmet Neşriyat, 2006), 246,248; Rağıb el İsfahânî, Müfredat-Kur'ân Kavramları Sözlüğü, çev. Abdulbaki Güneş - Mehmet Yolcu (PDF: Yarın Yayınları, 2015), 576; Mustafa Çağrıcı, "Sabır”, Türkiye Diyanet Vakfi İslâm Ansiklopedisi (Erişim 18 Eylül 2019).

${ }^{128}$ Kurân Yolu (Erişim 6 Nisan 2019), el-Bakara 2/250; Kur'ân Yolu (Erişim 6 Nisan 2019), Al-i İmran 3/120, 186; Kur'ân Yolu (Erişim 6 Nisan 2019), Yusuf 12/18.

129 Hayati Hökelekli, İnsani Değerler (İstanbul: Değerler Eğitimi Merkezi Yayınları, 2013), 117-120; Hasan Kayıklık, Tasavvuf Psikolojisi (Ankara: Akçağ Yayınları, 2.Basım, 2011), 150-152; Toshiko Izutsu, Kur'an'da Dini ve Ahlâki Kavramlar, çev. Selahattin Ayaz (istanbul: Pınar Yayınları, 2013), 177-178.

${ }^{130}$ Halil Bozkurt, Ebû Tâlib El-Mekkînin Kûtü'l-Kulûb Adlı Eserinde Tevekkül Kavramının Tasavvufi Seyirdeki Yeri (Bursa: Uludağ Üniversitesi, Sosyal Bilimler Enstitüsü, Yüksek Lisans Tezi, 2019), 70-74.

${ }^{131}$ Merter, Psikolojinin Üçüncü Boyutu Nefs Psikolojisi ve Rüyaların Dili, 221.

${ }^{132}$ Mevlânâ, Fîhi Mâ Fih, 22,24,57-58; Mevlânâ, Mesnevî, 1/4003b.

${ }^{133}$ Kuşeyrî, er-Risaletül-Kuşeyrîyye, 377.

${ }^{134}$ Mevlânâ, Mesnevî, 1/2910b, 3/3147b.

135 Mevlânâ, Mesnevî, 1/95b.

${ }^{136}$ Mevlânâ, Mesnevî, 3/1840-1850b,1/3795b.

${ }^{137}$ Mevlânâ, Mesnevî, 4/103,91-107b. 
metaforla sabır terapilerdeki kaçınmamayı, yüzleşerek, anlayarak, derin bir kavrayışla olgunlaşarak olayları çözümleme amacını desteklemektedir. Buna ilaveten Mesnevîd de dertten kaçmak yerine, düşünerek çözüme kavuşulacağ ${ }^{138}$ ile ilgili bölüm, kabullenmeyi sağlama, gözlem yapma yeteneğini geliştirme için cesaretlendirebilir.

5.2.3.Tevekkül: Sabırla ilişkili ve sıkça birlikte geçen bir diğer kavram tevekküldür. Kur'ân'daki tevekkül ile ilgili ayetlerde ${ }^{139}$ olayları olduğu gibi kabul etmek, sonucu Allah'a bırakmak anlamları vardır. Tevekkül kavramının bileşenlerinde duruma derin bir şekilde vakıf olma, tam olarak tüm yönleriyle idrak etme ${ }^{140}$ yer almaktadır. Bu şekilde davranarak kişi elinden gelmeyecek bir durum için üzülüp kendini yıpratmaktan vazgeçebilir. Tevekkülün bir amacı da üzüntünün yatışması, üzüntüden arınmaktır. ${ }^{141}$

Tevekkülde elinden geleni, kişinin gücünün yettiği kadarını yapmış olmanın huzuruyla ve ümitli bir bekleyişle sonucu Allah'a bırakma, gelecek kaygısının yerine güven duygusu $^{142}$ Mesnevîde birçok yerde küçük öykü, hikâye ve metaforlarla işlenmektedir. Bu anlamlarıyla İslam düşünce kaynaklarında sabır ve rıza gibi tevekkül de psikolojik bir kavram olarak işlenmiştir.

Tevekkül ile ilgili yapılan çalışmalarda, tevekkülün kabul etmeyi kolaylaştırdığı, iyimserliği artırdı̆̆ı, hayata bakış açısını genişlettiği, benlik saygısını yükselttiği tespit edilmiştir ${ }^{143}$ Şahin (2018) $)^{144}$ yaptığı çalışmada 'tevekkül yönelim modeli' geliştirmiştir. ${ }^{145}$ Tevekkülün kişiye belirsizliğe dayanıklı olma, kaygının azalması, başa çıkabilme, ümitli olma, kabullenme sağladığını, tevekkülün bir olayın öncesi ve sonrasında, meydana gelme süreci boyunca kullanılan pozitif bir yönelim olduğunu ${ }^{146}$ tespit etmiştir.

Tevekkülün psikolojik süreçlere olumlu katkısı, insanın olayları kontrol çabasıyla ilgilidir. Farkındalık ve kabul terapileri için aşırı kontrol çabası, yaşam kalitesini düşürmesi nedeniyle vazgeçilmesi amaçlardan bir durumdur. ${ }^{147}$ Tevekkül etmek, insanın çabasını aşan, kontrol edemeyeceği durumların oluşunu kabule yönlendirir. Başa çıkma ile ilgili yapılan bir çalışmada kontrolü mümkün olmayan durumları Allah'a havale ederek başa çıkan kişilerde psikolojik iyi oluş tespit edilmiştir. ${ }^{148}$ Olayları

138 Mevlana, Mesnevî, 2/1991b.

139 Kur'ân Yolu (Erişim 6 Nisan 2019), Hud 89/88; el-Bakara 2/156, 216; Al-i İmran 3/159; Kur'ân Yolu (Erişim 6 Nisan 2019), el-Ahzab, 33/48.

140 İsfahânî, Müfredat, 564-566.

141 Esma Sayın, Tasavvuf Terapisi (İstanbul: Nesil Yay, 2014), 182.

142 Mevlânâ, Mesnevî, 4/2899-2900b, 2/725-726b,1/961-962b, 4/2827-2828b, 3/429-430b, 4/2401-418b, 3/3094-3101b.

143 Meryem Şahin, Dini Bir Değer Olarak Tevekkül Yöneliminin Psikolojik Sebep ve Sonuçları Üzerine Araştırma (Bursa: Uludağ Üniversitesi, Sosyal Bilimler Enstitüsü, Doktora Tezi, 2018), 181-187; Kasım Karataş - Mustafa Baloğlu, “Tevekkülün Psikolojik Yansımaları”, Çukurova Üniversitesi İlahiyat Fakültesi Dergisi 19/1 (2019), 111; Fikret Karaman, “Tevekkül İnanc1 Üzerine Bir İnceleme”, Frat Üniversitesi İlahiyat Fakültesi Dergisi 1 (1996), 67-92.

144 Şahin, Dini Bir Değer Olarak Tevekkül Yöneliminin Psikolojik Sebep ve Sonuçları Üzerine Araştırma.

145 Şahin, Dini Bir Değer Olarak Tevekkül Yöneliminin Psikolojik Sebep ve Sonuçları Üzerine Araştırma.

146 Şahin, Dini Bir Değer Olarak Tevekkül Yöneliminin Psikolojik Sebep ve Sonuçları Üzerine Araştırma, 86, 153, 179.

147 Harris, ACT’i Kolay Öărenmek, çev. Hasan Turan Karatepe - K. Fatih Yavuz.

148 Ana Wong-Mc Donald - Richard L. Gorsuch, “Surrender To God: An Additional Coping Style?", Journal of Psychology and Theology 28/2 (2000). 
kontrol edemeyeceği bir noktada kişinin sınırlarını bilmesi ve olduğu gibi kabul etmesi sağlıklı bir yaklaşımdır. ${ }^{149}$

Buna ilaveten birçok İslami düşünce kontrol çabasını değerlendirmede farkındalık ve ACT için verimli olabilir. Örneğin İslam'da kişinin elinden gelmeyen durumları kontrol çabasıyla ilgili olarak; insanın çevreyi kontrol değil kendini kontrol edebileceği başkaları ile ilgili karar verici zorlayıcı olamayacağı ${ }^{150}$ ayeti de terapi sürecinde kullanılabilir.

5.2.4. Rıza: Rıza Sözlükte; hoşnut ve memnun olmak, tasvip etmek, beğenmek, karş1lıklı anlaşma ${ }^{151}$ huzur sevinç, ${ }^{152}$ anlamlarına gelmektedir. "Allah onlardan razı oldu, onlar da Allah'tan razı oldular" mealindeki ayetler ${ }^{153}$ Allah ile kul arasındaki rıza halinin karşılıklı olduğunu göstermektedir. İslam kaynaklarında rıza; olumsuz, acı yaşam deneyimleri içindeyken kalbin sakin ve huzurlu kalarak durumu kabullenmesi ${ }^{154}$ olarak tanımlanmıştır. Razı oluş sürecinde olumsuz olayı gözlemleme, varlığını kabul etme yanı sıra olumlu olaylara açık olma vardır. Razı olan kişi tevekkül ederek, olayları sürekli tekrarlayan (ruminatif) bir şekilde öfke ve yeisle zihninde döndürmeden kabullenmektedir.

İç içe geçmiş bu üç kavram sabır, tevekkül ve rıza kavramı, dindar danışanlar için kabullenmenin anlaşılabilir ve uygulanabilir olmasına yardımcı olacaktır.

5.2.5. Bilişsel Birleşmenin Çözümlenmesi İçin Bilişsel Ayrışma: Kişinin yaşadığı olumsuz olayları benliğinin bir parçası olarak kabul etmesi ve kendini olumsuz tanımlaması bilişsel birleşmedir. Bilişsel ayrılma ise hoşa gitmeyen, olumsuz, başarısızlıkla vb. sonuçlanan deneyimlerimizin yaşam içinde karşılaşılan durumlar olduğunu görmek ve kişiliğimizi tanımlama şekli yapmaktan vazgeçmektir. ${ }^{155}$ Bilişsel ayrışma ise, olayları kötü olarak etiketlemeden, yargilamadan olduğu gibi algılamak, kabul etmek ve benliğin bir parçası olarak görmek yerine, geçip gitmelerine izin vermek, serbest bırakmaktır. ${ }^{156}$ Olumsuz düşünceden kaçınmak ya da bastırmak, onların içinde boğulmak yerine ayrışmak, oldukları gibi, kendine şefkat göstererek kabul etmek beraberinde değişimi getirecektir.

İslam zihnin sürekli olumsuz düşüncelerle meşgul olmasını "vesvese" ile tanımlar. Vesvese; "fisıldama, kötü telkinde bulunma, karışı sözler söyleme, kuşkulanma", aynı kökten vesvâs: "insanın içine doğan zararlı uyarıcı, kötü duygu ve düşünce, telkin, şüphe, fisıltı, evham" anlamlarındadır. ${ }^{157}$ Kur'ân vesvese yani zihne tekrar tekrar gelen olumsuz

\footnotetext{
149 İbrahim Gürses, Kölelikve Özgürlük Arasında Din (Bursa: Arasta Yayınları, 2001), 78.

${ }^{150}$ Kur'ân Yolu (Erişim 6 Nisan 2019), el- Gâş̧iye 88/22.

151 İsfahânî, Müfredat, 430; İbn Arabî, Fütühat-ı Mekkiye, Rıza İhlas ve Tevekkül, çev. Ekrem Demirli (İstanbul: Litera Yayıncilık, 2. Basım, 2016), 28.

152 Kuşeyrî, er-Risaletül-Kuşeyrîyye, 269-274.

153 el-Bakara 2/232; Kur'ân Yolu (Erişim 6 Nisan 2019), el-Mâide 5/119; Kur'ân Yolu (Erişim 6 Nisan 2019), elMücâdile 58/22; Kur'ân Yolu (Erişim 6 Nisan 2019), el-Fecr 89/28-30; Kur'ân Yolu (Erişim 6 Nisan 2019), elBeyyine 98/8.

154 Kuşeyrî, er-Risaletül-Kuşeyrîyye, 321; Ebû Hâmid Muhammed el Gazzâlî, İhya'u' ulumi'd-din, çev. Ahmet Serdaroğlu (ìstanbul: Bedir Yayınları, 1986), 4/337.

155 Ögel, Farkındalı Ayrımsama ve Kabullenme Temelli Terapiler; Yavuz, “Kabul ve Kararlılık Terapisi (ACT): Genel Bir Bakıș”; Harris, ACT'i Kolay Öğrenmek.

156 Ögel, Farkındalık Ayrımsama ve Kabullenme Temelli Terapiler, 83; Yavuz, "Kabul ve Kararlılık Terapisi (ACT): Genel Bir Bakış”, 26.

${ }^{157}$ Mustafa Çağrıcı, “Vesvese”, Türkiye Diyanet Vakfi İslâm Ansiklopedisi (Erişim 18 Eylül 2019).
} 
düșünceden uzak durulmasını1 ${ }^{158}$ vurgulamıștır. Bu açılama, inançlı bir danışanın olumsuz düşüncelerden sıyrılmasını sağlamakta yardımcı olabilir.

Buna ilaveten Müslüman bir danışan Kur'an'ın insana verdiği önem ve değere ${ }^{159}$ bağlandığında olumsuz düşüncelerin varlığının özünden olmadı̆̆ını bilmesi onlardan ayrışma ve gitmelerine izin vermeyi kolaylaştırabilir.

5.2.6. An İle Temasın Kaybolmaması İçin Çözüm, Anda Kalma: An ile temasın kaybolması geçmiş ve gelecekle ilgili olumsuz düşüncelerin zihinde dolaşmasından kaynaklanmaktadır. Zihnin bu olumsuz etkilerden arınmasını sağlamak bilişsel davranışçı terapi ve farkındalık terapilerinin ${ }^{160}$ ortak noktasıdır. Farkındalık terapisi alan kişiler ve sufi yaşantıda olan kişiler olumsuz düşünce ve kaygılardan uzaklaşabilmektedirler. ${ }^{161}$

İslam'da anda olmayı sağlayan düşünce geleneği: İçinde yaşanılan zaman dilimine yoğunlaşma ve ana odaklanma Tasavvufta “ibnü'l-vakt olmak” olarak tanımlanmış ve kazanılması gereken iyi bir özellik olarak görülmüştür. İbnü'l vakt olma; geçmişte kalmadan, gelecekle ilgili kaygı taşımadan içinde bulunulan anı verimli, gereklerini fark ederek, yerine getirerek yaşamak, huzurlu bir şekilde değerlendirmektir. ${ }^{162} \mathrm{Bu}$ düşünce kaynağını ayet ve hadislerden almaktadır, örneğin "Göklerde ve yerde bulunan herkes, O'ndan ister. O, her anyaratma halindedir" ayeti ${ }^{163}$ ve "iki günü eşit olan zarardadır" hadisi ${ }^{164}$ verilebilir. Hadis alan yazında "bu hadis Hz. Muhammed'in hayatın her anında açık, şeffaf, dinamik bir yaşam tarzı benimsediğinin, varolmanın bilincinde ve neşesinde her an var oluşun doyumsuz zirvesinde yaşadığlnın açık bir kanitıdır ve bu yönüyle $\mathrm{Hz}$. Peygamber proaktif, sürekli üreten, üretmek için yaşayan bir modeldir" ${ }^{\prime 165}$ şeklinde yorumlanmıştır. Anda olmakla ilgili İslam kaynaklarından çıkarılabilecek anlayış, hayatın ve her anının bilinçli ve bu eşsiz deneyime kıymet vererek yaşanması yönündedir.

\subsubsection{Kavramsallaştırılmış Benliğe Bağlanmanın Çözümü Olarak Gözlemleyen Ben-} lik: Benliğin kavramsallaştırılması kişilerin kendilerini nasıl algıladıkları ve tanımladıkları ile ilgilidir. Kişinin geçmiş bazı olumsuz deneyimler nedeniyle kendisiyle ilgili yorumlayıcı ve yargılayıcı hikâyeleri vardı1 ${ }^{166}$ "ben alkoliğim” gibi. Gözlemleyen benlik ise kişinin kendisinin olumsuz deneyimlerden ayrıştırması, deneyimlerinin içeriğinden ibaret olmadı̆̆ı

158 Kur'ân Yolu (Erişim 6 Nisan 2019), Kaf 50/16; Kur'ân Yolu (Erişim 6 Nisan 2019), el-Nas 114/4, 5.

159 Kur'ân Yolu (Erişim 6 Nisan 2019), el-İsrâ 17/70; Kur'ân Yolu (Erişim 6 Nisan 2019), Tîn: 95/4; Kur'ân Yolu (Erişim 6 Nisan 2019), el- Nahl 16/12.

160 Ögel, Farkındalık Ayrımsama ve Kabullenme Temelli Terapiler; Hakan Türkçapar, _Bilişsel Davranış̧̧ı Terapi: Temelleri ve Ötesi.

161 Ögel, Farkındalık Ayrımsama ve Kabullenme Temelli Terapiler.

162 Semih Ceyhan, "Vakit”, Türkiye Diyanet Vakfi İslâm Ansiklopedisi (Erişim 18 Eylül 2019); Mehmet Demirci, "Hal”, Türkiye Diyanet Vakfi İslâm Ansiklopedisi (Erişim 18 Eylül 2019); Kuşeyrî, er-Risaletül-Kuşeyrîyye, 124,126; Mevlânâ, Mesnevî 1/133b.

163 Kur'ân Yolu (Erişim 6 Nisan 2019), el- Rahman 55/29.

164 İsmâil b. Muhammed el-Aclûnî, Keşfü'l-ḩafâ, nşr. Ahmed el-Kalâş (Beyrut: Mektebetü ilmil hadis, 1985), 2/274. Geniş bilgi için bk. Deylemi, Firdevs).

165 Behlül Tokur, Kişisel Gelişim (NLP)-Din İlişkisi Üzerine Bir Araştırma (Erzurum: Atatürk Üniversitesi, Sosyal Bilimler Enstitüsü, Yüksek Lisans Tezi, 2006), 125.

166 Yavuz, "Kabul ve Kararlılık Terapisi (ACT): Genel Bir Bakış", 25; Ögel, Farkındalık Ayrımsama ve Kabullenme Temelli Terapiler, 84. 
ayrı bir benliğinin olduğunu fark etmesidir. ACT benlik ile olaylar arasındaki ilişki üzerinden kişilik tanımlaması yapmak yerine, olayları gözlemleyip, geçip gitmelerine izin verilmesini amaçlar. Bunu sağlamak için içinde bulunduğu anın farkında olmak, olayları geride bırakmak önemlidir.

İslam'daki tövbe anlavıșı kișinin olumsuz davranıslardan avrıșmasını sağlar. Tövbe "geri dönmek, rücû etmek, dönüs yapmak" ve "olumsuz şeyleri terk edip övgüye lâyık olanlara yönelme" anlamındadır. ${ }^{167}$

Tövbe ile ilgili ayetlerde yaptı̆̆ı davranışın olumsuzluğunu fark ederek bundan dolayı üzülmek, pişmanlık duymak ve bunun neticesinde iyi davranışlara yönelmek övülmektedir. ${ }^{168}$ Tövbedeki "Pişmanlık" önemli görülmüştür; davranışının neden yanlış olduğunu anlamak ve bundan dolayı üzülme süreci olan pişmanlığın içinde davranışın olumsuzluğunu fark etme, bir uyanış, kararlı bir davranış söz konusudur. Buna ilaveten tövbede kararlı olma gereklidir. ${ }^{169}$

Gazzâlî tövbeyi "zahmet ve acı veren elbiseyi çıarıp faydalı elbiseyi giymektir"170 şeklinde ifade etmiştir. Bu metafor farkındalık ve ACT terapilerinde dini danışanlar için uygulanabilir. Böylece kavramsallaştırılmış olumsuz benlik kötü elbiseye benzetilerek kişinin kendisi olmadığı, istenirse çıkarılıp, yerine güzel ve yakışan bir elbise gibi olumlu davranışların seçilerek giyebileceği kanaati oluşturulabilir. Bu örnekte bilişsel ayrışma ve gitmesine izin verme vardır. Kötü davranışın elbise gibi çlkarılabilir ve yerine güzel iyi olanın giyilebilir oluşu, Müslüman danışanlar için terapinin benimsenmesinde etkili olabilir.

İslam dini kavramlarından tövbe ile kabul ve kararlılık terapisi kavramları arasındaki uyum her ikisinde de eylemin değișen davranışa odaklanmasıdır. Müslüman danışanların kendi hikâyeleri günahlarla bağlantılı olsa bile, tövbeden önceki eski hikâyeye bağlı kalmalarına gerek yoktur. ${ }^{171}$ Tövbe süreci olumsuz davranışı kabul ve farkındalıkla başlar. Tövbe sürecinde kabullenme terapileri için önemli olan bilişsel ayrışma, kendini olumsuz hikâyeden ayırma vardır. Buna ilaveten olumsuz davranışlardan vazgeçerek ve iyi davranışlara yönelerek değerlere bağlı yaşamaya kararlı olmanın gerekliliği tövbe etmeyle ilgili ayetlerde açıkça görülmektedir.

Olumsuz düşüncelerden bilişsel ayrışma için tövbeden başka kaynaklar kullanılabilir. Yerine göre, örneğin değersiz hisseden bir kişi için bu histen tövbe ile değil kendine değer verme ayetleri ile eşrefi mahlûkat, en değerli varlı ${ }^{172}$ olma ile bilişsel ayrışma sağlanabilir.

5.2.8. Değerlerden Uzaklaşma/ Değerlere Yönelme ve Değişime Kararlılık: Değerler kişi için anlamı olan yaşamını anlamlı kılan hayat görüşüdür, ${ }^{173}$ aile sahibi olmak, çocuk-

167 Uludağ, “Tövbe”, Türkiye Diyanet Vakfi İslâm Ansiklopedisi (Erişim 18 Eylül 2019).

168 Kur'ân Yolu (Erişim 6 Nisan 2019), el-Furkân, 25/68-71; el-Bakara 37/54,128,160, 187; Âl-i İmrân 3/89; elMâide 5/39).

169 Ebû Hâmid Muhammed el Gazzâlî, Abidler Yolu, çev. Ali Bayram - Sadi Çögenli (İstanbul: Çelik Yayınevi, 2. Basım, 2019), 40-45; Kuşeyrî, er-Risaletül-Kuşeyrîyye, 170.

170 Gazzâlî, İhyau Ulumi'd-Din, 11/147.

171 Yavuz, "ACT and Islam" 139-149.

172 Tîn 95/4.

173 Ögel, Farkındalık Ayrımsama ve Kabullenme Temelli Terapiler, 84, 85. 
larını iyi yetiştirmek, kariyer sahibi olmak gibi. Bundan önceki ACT adımları kişinin olumsuz düşünceleriyle mücadelesini ve zihnini bunlardan arındırma süreçlerini ortaya koymaktadır. Olumsuz düşünceler kişiyi anlamlı bir hayat yaşamaktan uzaklaştırır. Buraya kadar olan; kabullenme, bilişsel ayrışma, anla temas, kendini gözlemleyebilme becerileri kazanılması süreçleri, zihni olumsuz düşüncelerden arındırma ve kişinin kendi değerlerine uygun yaşama hazır hale gelmesi içindir. ACT için değerlere sahip olma ve kararlı bir biçimde değerlere yönelik yaşam nihai adımdır. ${ }^{174}$

Dini inançlar bu değerlere kaynaklık edebilir. ${ }^{175}$ İslam, değerlerle ve anlamlı bir şekilde yaşamaya önem verir. Üzüntülü zamanlarda örneğin "rabbin seni ne terk etti ne de sana darıld»"176 anlamındaki Allah'ın inananlarla birlikte olduğuna yönelik ayetler yalnızlık hissini azaltma, manevi güç bulma sağlayabilir. Bunun gibi inananların zor zamanlarda birbirine destek olması, iyilik tavsiye etmesine, ${ }^{177}$ yardımlaşmaya yönelik ${ }^{178}$ ayetler sosyal hayatı anlamlı kılar. Kişiler arası ilişkilerdeki değer verme ve değerli hissetmeye yönelik, örneğin eşlerin birbirini tamamlaması, insanların birbirine iyi davranması, ayıplamaması, aşağılamaması, alay etmemesini açıklayan sureler ${ }^{179}$ ve İslam dininin tamamı değerlere yönelik, anlam, amaç ve değerlerle dolu bir yaşamı emir ve tavsiye etmektedir.

ACT ile İslam arasındaki geniş kavramsal örtüşme nedeniyle, İslam ACT ve bağlamsal davranış bilimine önemli katkı yapma potansiyeline sahiptir. Bu benzerliklerin farkında olmak, Müslüman danışanlara yardımcı olabilir. ${ }^{180}$

\section{Tartışma, Sonuç ve Öneriler}

Psikoterapi süreçlerine manevi ve dini değerlerin entegre edilmesi batıda artık tartışılan değil, yöntem haline getirilen bir süreçtir. Psikoterapilere dini değerlerin entegre edilmesi dini, psikoloji kavramı haline getirme ya da psikolojiyi dindar bir hale getirme çabası değildir. Psikoloji bilimi tarafından dini değerlerin insanın duygu düşünce dünyasındaki önemi keşfedilmiş ve dindar danışanların, kendi kaynaklarıyla güçlenmelerini sağlamak, böylece terapi sürecini zengin kaynaklar kullanarak etkin ve verimli hale getirmek amaçlanmıştır.

Farkındalık ve kabullenme terapileri, terapötik süreçte ortak stratejiler kullanmaktadır. Bunlar şimdiye odaklanma, yargısızlık, kabullenme, gözlem ve bilişsel ayrışmadır. Bu adımlara uygun uygulama, hikâye ve metaforlar başlangıçta Budizm içinden kaynak bulsa da uygulama ve hikâye seçiminde sınır olmadığı için, dinlerin zengin kavramları ve bu çalışma için dikkate alınan İslam'ın zengin kaynakları terapi süreçlerine dahil edilebilir bulunmuştur, dahil edilmektedir.

Farkındalık uygulamaları çok çeşitlidir, sese odaklanma, yiyeceklere odaklanma, vücuda odaklanma vb. yüzlerce örnekle sağlanabilmektedir. Örneğin “üzüm yeme” psikoloji

\footnotetext{
174 Harris, ACT’i Kolay Öğrenmek, çev. Hasan Turan Karatepe - K. Fatih Yavuz; Yavuz, "Kabul ve Kararlılık Terapisi (ACT): Genel Bir Bakış”; Ögel, Farkındalık Ayrımsama ve Kabullenme Temelli Terapiler, 83-86.

175 Herbert-Forman, Acceptace and Mindfulness in Cognitive Behavior Theraphy Understanding and Applying, 243.

176 Kur'ân Yolu (Erișim 6 Nisan 2019), Duhâ 93/3.

177 Kur'ân Yolu (Erişim 6 Nisan 2019), el-Asr 103/3.

178 el-Bakara 2/177.

179 Kur'ân Yolu (Erişim 6 Nisan 2019), Lokman 31/1-34; Kur'ân Yolu (Erişim 6 Nisan 2019), el-Hucurat 49/1-18.

180 Yavuz, “ACT and Islam”, 139-149.
} 
kavramı değildir, üzüm yemeye terapi değeri veren şudur; eğer üzüm yerken odaklanır ve kendi benliğimizi hissedebilirsek, bu bize anda kalma becerisi kazandırabilir ve zamanla günlük hayatımızı daha bilinçli yaşamamıza yardımcı olabilir. Bu Müslüman danışan için neden zikir olmasın? Olabilir, psikoterapiler dinlerin derin eşssiz deneyimlerini dindar danışanlar için uygulamalarına dâhil etmektedirler.

Kabullenmenin iyileştirici psikolojik bir süreç olduğunun tespitini yapan ve terapi yöntemi geliştiren psikolojiye, dindar danışanlar için, örneğin, İslami bir kavram olan rıza ile katkı verilmesi zenginlik olarak görülmektedir. Psikoloji camiasının yurtdışı ve yurt içi çalışmalarında, özellikle Mesnevî sıklıkla kullanılmaktadır. İslam kaynakları psikoterapiye katkı vermek için bu sınırlı araştırmada yer alanlardan çok daha fazlasına sahiptir.

$\mathrm{Bu}$ araştırmada dindar danışanlar için İslam dini kaynaklarının farkındalık ve ACT için kaynak sağlama durumu incelenmiştir. Zengin İslam düşüncesinden kısa kesitlerle, ibadetlerin farkındalık sağladığı ve terapinin pratiklerinde uygulanabileceği tartışılmıştır. Kabul ve kararlılık terapileri için,

* Kabullenme ile rıza,

* Sonuca yönelik kontrol çabasını bırakma ile tevekkül,

* Olumsuz duygu ve düşünceleri gözlemleyebilme ile sabır,

* Bilişsel ayrışma için tövbe ve değerli olma kavramları arasındaki bilişsel uyum ortaya konulmaya çalışılmıştır.

İslam değerlerle dolu bir yaşam sunmaktadır, çalışma, ümitli olma, güzel bir yaşam içinde olma aileye bağlılık, sosyal yaşam gibi hayatın her alanı için insanın mutluluğunu esas alan değerlerle doludur.

Bu araştırmada İslam kaynaklarından sınırlı, küçük bir kesit sunulmuştur, geniş İslam düşüncesinde terapi değeri olan birçok kavram incelenmelidir. İslam düşünce geleneği hazinelerle doludur, bu örnekler çoğaltılabilir, dindar danışanlar için psikoloji ve din psikolojisi camiası birbirine destek ve katkı vererek psikolojik değeri olan daha birçok dini kavramı uygulamaya dâhil etme üzerinde çalışabilir.

\section{Kaynakça}

Aclûnî, İsmâil b. Muhammed. Keşfül'-hafa ve müzîlül'-ilbas amme'ş- tehara mine'l-ehâdîs alâ elsineti'n-nâs. nşr. Ahmed el-Kalâş. Beyrut: Mektebetü'l-İlmi'l-Hadis. 1985.

Ak, Mehmet vd.. "Mevlânâ Penceresinden Bilişsel Terapiler". Bilişsel Davranış̧̧ Psikoterapi ve Araştırmalar Dergisi 3 (2014), 133-141.

Appel, Jonathan - Kim-Appel, Dohee. "Mindfulness: Implications for Substance Abuse and Addiction". Int J Ment Health Addiction 7 (2009), 506-512. DOI 10.1007/s11469-009-9199

Arabî, İbn. Fütühat-ı Mekkiye, Rıza İhlas ve Tevekkül. çev. Ekrem Demirli. İstanbul: Litera Yayıncılık, 2. Basım, 2016.

Aslami, Elahe vd.. "A Comparative Study of Mindfulness Effciency Based on Islamic-Spiritual Schemes and Group Cognitive Behavioral Therapv on Reduction of Anxiety and Depression in Pregnant Women". Int J Community Based Nurs Midwifery 5/2 (2017),144-152.

Attar, Feridüddin. Mantıku't Tayr. çev. Abdülbaki Gölpınarlı. İstanbul: Meb Yayınları, 2001.

Beck, Judith S. BDT Temelleri ve Ötesi. çev. Muzaffer Şahin. İstanbul: Nobel Yayınları. 2016.

Behrens, Rosemary D. - Terrill, Jerry L. "The Navigation Tools of Spiritual Mindfulness". (2011). Retrieved from http://counselingoutfitters.com/vistas/vistas11/Article_100.pdf

Bingaman, Kirk A. "The Art of Contemplative and Mindfulness Practice: Incorporating the Findings of Neuroscience into Pastoral Care and Counseling". Pastoral Psychology 60 (2011), 477-489. 
Birnbaum, L.- Birnbaum, A. "Mindful Social Work: From Theory to Practice". Journal of Religion \& Spirituality in Social Work: Social Thought 27/1-2 (2008), 87-104. doi: 10.1080/15426430802113913

Birnie, Kathryn vd.. "Exploring Self-compassion and Empathy in the Context of Mindfulness-based Stress Reduction (MBSR)". Stress and Health 26 (2010), 359-371.

Bozkurt, Halil. Ebû Tâlib El-Mekkînin Kûtü'l-Kulûb Adhl Eserinde Tevekkül Kavraminin Tasavvufí Seyirdeki Yeri. Bursa: Uludağ Üniversitesi, Sosyal Bilimler Enstitüsü, Yüksek Lisans Tezi, 2019.

Buhârî, Ebû Abdillâh Muhammed b. İsmail. et-Tecrîdü's-sarîh li-ehâdîsi'l-Câmiti's-sahîh. çev. Kamil Miras. Ankara: Diyanet İşleri Başkanlığı Yayınları, 1976.

Çağrıcı, Mustafa. “Sabır”. Türkiye Diyanet Vakfi İslâm Ansiklopedisi. Erişim 18 Eylül 2019.

https://islamansiklopedisi.org.tr/sabir

Çağrıcı, Mustafa. "Vesvese”. Türkiye Diyanet Vakfi İslâm Ansiklopedisi. Erişim 18 Eylül 2019.

https://islamansiklopedisi.org.tr/vesvese

Carmody,James vd.. "Mindfulness, spirituality and health-related symptoms". Journal of Psychosomatic Research 64 (2008), 393-403.

Carmody,James vd.. "An Empirical Study of the Mechanisms of Mindfulness in a Mindfulness-Based Stress Reduction Program”. Journal of Clinical Psychology 65/6 (2009), 613-626. DOI: 10.1002/jclp. 20579

Ceyhan, Semih. “Vakit”. Türkiye Diyanet Vakfi İslâm Ansiklopedisi. Erişim 18 Eylül 2019. https://islamansiklopedisi.org.tr/vakit--tasavvuf

Chafos, Vanessa H. - Economou, Peter. "Beyond Borderline Personality Disorder: The Mindful Brain”. Social Work Volume 59/4 (2014), 297-302. doi: 10.1093/sw/swu030

Connors, Mary E.. "Integrative Symptom-Focused Dynamic Psychotherapy”. Clinical Social Work Journal 20/1 (2010), 37-45. doi: 10.1007/s10615-010-0280-7

Crane, Rebecca. Mindfulness-Based Cognitive Therapy: Distinctive Features. London and New York: Taylor \& Francis, 2.nd Edition, 2017.

Çatak, Pelin Devrim - Ögel, Kültegin. "Farkındalık Temelli Terapiler ve Terapötik Süreçler”. Klinik Psikiyatri 13 (2010), 85-91.

Demir, Volkan. "Bilinçli Farkındalık Temelli Bilişsel Terapi Programının Üniversite Öğrencilerinin Kaygı Düzeylerine Etkisi”. OPUS Uluslararası Toplum Araştırmaları Dergisi 7/12 (2017), 98-118. DOI: 10.26466/opus.294058

Demirci, Mehmet. “Hal”. Türkiye Diyanet Vakfi İslâm Ansiklopedisi. Erişim 18 Eylül 2019. https://islamansiklopedisi.org.tr/hal--tasavvuf

Demirci, Mehmet. “Kur’an-1 Kerim Işı̆̆ında Sabır Kavramı”. Sosyal Bilimler Enstitüsü Dergisi 12/20 (2002), 263-285.

Ecmel, Muhammed. "Sûfî Ruhbilimi”. Sufi Psikolojisi. ed. Kemal Sayar. 97-115. İstanbul: Timaş Yayınları, 2008.

Eifring, Halvor. Meditation in Judaism, Christianity and Islam: Technical Aspects of Devotional Practices. London: Bloomsbury Academic, 2018.

Ekşi, Halil. (ed.). Psikoterapi ve Psikolojik Danışmada Maneviyat Kuramlar ve Uygulamalar. İstanbul: Kaknüs Yayınları, 2017.

Flavell, John H.. Cognitive Development. Englewood Cliffs, N.J. : Prentice-Hall,1985.

Frager, Robert. Kalp, Nefs ve Ruh. çev. İbrahim Kapaklıkaya. İstanbul: Gelenek Yayınları, 2003.

Gazzâlî, Ebû Hâmid Muhammed. Abidler Yolu. çev. Ali Bayram - Sadi Çögenli. İstanbul: Çelik Yayınevi, 2. Basım, 2019.

Gazzâlî, Ebû Hâmid Muhammed. Bidayetü'l-hidâye. nşr. Veysel Akkaya. İstanbul: İnsan Yayınları İrfan Tasavvuf Serisi, 2003.

http://www.ahmettunalilar.com/Kitaplar/imam_Gazali-Hidayet_Rehberi.pdf

Gazzâlî, Ebû Hâmid Muhammed. İhya'u' ulumi'd-din. çev. Ahmet Serdaroğlu. İstanbul: Bedir Yayınları, 1986. 
Gockel, A. vd.. "Mindfulness as Clinical Training: Student Perspectives on the Utility of Mindfulness Training in Fostering Clinical Intervention Skills". Journal of Religion \& Spirituality in Social Work: Social Thought 32/1 (2013), 36-59. doi:10.1080/15426432.2013.749146

Gordon, David Jacobs. A Critical History of Mindfulness-Based Psychology. Middletown, CT, United States: Wesleyan University, Artswith Departmental Honors in Psychology and the Science in Society Program, Degree of Bachelor Thesis, 2009.

Gölpınarlı, Abdülbaki. Mevlânâ Celaleddin-i Rumi Mesnevî Şerhi. İstanbul: Başbakanlık Kültür Müsteşarlığı Kültür Yayınları, 1974.

Grabbe, Linda. "Spirituality Development for Homeless Youth: A Mindfulness Meditation Feasibility Pilot". J Child Fam Stud 21 (2012), 925-937. DOI 10.1007/s10826-011-9552-2

Grabovac, Andrea D. vd.. "Mechanisms of Mindfulness: A Buddhist Psychological Model”. Mindfulness 2 (2011), 154-166. https://doi.org/10.1007/s12671-011-0054-5

Greeson, Jeffrey M. "Decreased Symptoms of Depression After Mindfulness-Based Stress Reduction: Potential Moderating Effects of Religiosity, Spirituality, Trait Mindfulness, Sex, and Age". J Altern Complement Med 21/3 (2015), 166-174. doi: 10.1089/acm.2014.0285

Gürses, İbrahim. Kölelik ve Özgürlük Arasında Din. Bursa: Arasta Yayınları, 2001.

Hafizi, Sina. "Borderline Personality Disorder and Religion: A perspective from a Muslim country". Iran J Psychiatry 9/3 (2014), 137-141.

Harris, Russ. Kabul ve Kararlllk Terapisi ACT’i Kolay Öğrenmek illkeler ve Ötesi İçin Hızlı Bir Bașlangıç. çev. Hasan Turan Karatepe - K. Fatih Yavuz. Litera Yayınc1lk, 2018.

Herbert, James D. - Forman, Evan, M.. Acceptace and Mindfulness in Cognitive Behavior Theraphy Understanding and Applying. Hoboken, New Jersey, United States: John Wiley \& Sons, Inc. 2010

Hick, Steven F.. Mindfulness and Social Work Practice. Chicago: Lyceum Books, 2009.

Hökelekli, Hayati. İnsani Değerler. İstanbul: Değerler Eğitimi Merkezi Yayınları, 2013.

Isgandarova, Nazila. "Muraqaba as a Mindfulness-Based Therapy in Islamic Psychotherapy". Journal of Religion and Health August 58/4 (2019), 1146-1160.

Izutsu, Toshiko. Kur'an'da Dini ve Ahlâki Kavramlar, çev. Selahattin Ayaz. İstanbul:Pınar Yayınları, 2013.

İsfahânî, Rağıb. Müfredat- Kur'ân Kavramları Sözlüğü. çev. Abdulbaki Güneş - Mehmet Yolcu. PDF: Yarın Yayınları, 2015. https://archive.org/details/MufredatIsfahaniKur'ân KavramlariSozlugu/page/n3

James, William. The Varieties of Religious Experience a Study in Human Nature. PDF: eBooks@Adelaide, 2009. https://pdfs.semanticscholar.org/05e7/aead0b75fb88b43a4bd19285760c0d3a a1e3.pdf

Kabat Zinn J. "Mindfulness-Based Interventions in Context: Past, Present, and Future". Clinical Psychology: Science and Practice 10 (2003), 144-156.

Kabat-Zinn J. Full Catastrophe Living: Using the Wisdom of Your Body and Mind to Face Stress, Pain, and Illness. New York: Bantam Dell Publishing, 1990.

Karekla, Maria - Constantinou, Marios. "Religious Coping and Cancer: Proposing an Acceptance and Commitment Therapy Approach". Cognitive and Behavioral Practice 17/4 (2010), 371-381.

https://doi.org/10.1016/j.cbpra.2009.08.003

Karaman, Fikret. “Tevekkül İnancı Üzerine Bir İnceleme”. Firat Üniversitesi İlahiyat Fakültesi Dergisi 1 (1996), 67-92.

Karataş, Kasım - Baloğlu, Mustafa. “Tevekkülün Psikolojik Yansımaları”. Çukurova Üniversitesi İlahiyat Fakültesi Dergisi 19/1 (2019), 111-118.

Kayıklık, Hasan. Tasavvuf Psikolojisi. Ankara: Akçağ Yayınları, 2.Basım, 2011.

Knabb, J.. "Centering Prayer as an Alternative to Mindfulness-Based Cognitive Therapy for Depression Relapse Prevention". Journal of Religion and Health 51/3 (2012), 908-924.

Kuşeyri, Abdülkerim. er-Risaletül-Kuşeyriyye. çev. Ali Arslan. İstanbul: Hikmet Neşriyat, 2006.

Kurân Yolu. Erişim 6 Nisan 2019. https://kuran.diyanet.gov.tr

Kutluer, İlhan. "Düşünme”. Türkiye Diyanet Vakfi İslâm Ansiklopedisi. Erişim 18 Eylül 2019. https://islamansiklopedisi.org.tr/dusunme 
Labelle, Laura E. vd.. “Does Self-Report Mindfulness Mediate the Effect of Mindfulness-Based Stress Reduction (MBSR) on Spirituality and Posttraumatic Growth in Cancer Patients?". The Journal of Positive Psychology 10/2 (2015), 153-166. DOI:10.1080/17439760.2014.927902

Lazaridou, Asimina - Pentaris, Panagiotis. "Mindfulness and Spirituality: Therapeutic Perspectives". Person-Centered \& Experiential Psychotherapies 15/3 (2016), 235-244.

Leigh, Janis vd.. "Spirituality, Mindfulness and Substance Abuse". September Addictive Behaviors 30/7 (2005), 1335-1341. DOI: 10.1016/j.addbeh.2005.01.010

Mc Cartney, Laura Lynn. Counsellors' Perspectives on How Mindfulness Meditation Influences Counsellor Presence Within the Therapeutic Relationship. Calgary, Canada: University of Calgary, Department of Educational Psychology and Leadership Studies, Degree of Master of Arts, 2000.

Merter, Mustafa. Psikolojinin Üçüncü Boyutu Nefs Psikolojisi ve Rüyaların Dili. İstanbul: Kaknüs Yayınları, 2014.

Mevlânâ Celaleddin-i Rumi. Fihi Ma Fih. Çev. Ahmed Avni Konuk PDF: İz Yayıncıllk, 2006. https://archive.org/details/FihiMaFih/page/n23

Mevlânâ Celaleddin-i Rumi. Mesnevî. http://www.masnavi.net

Miller, L.M. "The Experience of Prayer With a Sacred Object Within the Context of Significant Life Stress". Journal of Spirituality in Mental Health 13/4 (2011), 247-271.

Mirdal, G. "Mevlânâ Jalāl-ad-Dīn Rumi and Mindfulness". Journal of Religion and Health 51/4 (2012), 1202-1215.

Mutter, Kelvin. "The Practice of Mindfulness in Spiritual Care". Psychotherapy: Cure of the Soul. Ed. Thomas St. James O'Connor vd.. 131-138. Waterloo, Canada: Waterloo Lutheran Seminary, 2014.

Myers, Mark Joseph. Examinina the Relationship Between Mindfulness, Religious Coping Strategies, and Emotion Regulation. Lynchburg, VA, United States: Liberty University, A Dissertation Submitted in Partial Fulfillment of the Requirements for the Degree of Doctor of Philosophy, 2012.

Nieuwsma, Jason A. vd.. ACT for Clergy and Pastoral Counselors: Using Acceptance and Commitment Therapy to Bridge. Psychological and Spiritual Care. Oackland CA United States: New Harbinger Publications Inc., 2016.

Omar S.H. S. vd.. "Techniques of Practicing Muraqaba by Sufis in Malay Archipelago". International Journal of Academic Research in Business and Social Sciences 7/5 (2017), 347-357.

Ögel, Kültegin. Farkındalk Ayrımsama ve Kabullenme Temelli Terapiler. Ankara: HYB yayıncılık, 2.basım, 2015.

Öngören, Reşat. “Zikir”. Türkiye Diyanet Vakfi İslâm Ansiklopedisi. Erişim 18 Eylül 2019 https://islamansiklopedisi.org.tr/zikir\#1

Özelsel-Michaela, Mihriban. Halvette Kırk Gün. çev. Petek Budanur. İstanbul: Kaknüs Yayınları, 2002.

Parrot, Justin. "How to be a Mindful Muslim: An Exercise in Islamic Meditation". Yaqeen Institute for Islamic Research (2017), 1-24.

Peker, Hüseyin. Din Psikolojisi. İstanbul: Çamlıca Yayınları, 2011.

Percy, Ian. Mindfulness in Counsellina and Psychotherapy: Narratives from Practitioners in Bhutan and Australia. Bentley WA Australia: Curtin University, Thesis Doctor of Philosophy, 2017. DOI: 10.13140/RG.2.2.20412.23688

Priya, Gagan - Kalra, Sanjay. "Mind-Body Interactions and Mindfulness Meditation in Diabetes". EurOPEAN EndocrinoloGY 14/1 (2018), 35-41.

Progoff, Ira. The Death and Rebirth of Psychology. New York: Mc Graw-Hill, 1969. https://archive.org/details/deathrebirthofps001553mbp/page/n15

Saddigha, Al-Ghalib vd.. "A mindfulness based intervention to enhance university student wellbeing in Saudi Arabia". Middle East Journal of Positive Psychology 4/1 (2018), 142-157.

Saniotis, Arthur. "Understanding Mind/Body Medicine from Muslim Religious Practices of Salat and Dhikr". Journal of Religion and Health 57/3 (2018), 849-857. doi:10.1007/s10943-014-9992-2

Sayın, Esma. Tasavvuf Terapisi. İstanbul: Nesil Yay, 2014. 
Sharma, Manoj - Rush, Sarah E.. "Mindfulness-Based Stress Reduction as a Stress Management Intervention for Healthy Individuals: A Systematic Review". Journal of Evidence-Based Complementary \& Alternative Medicine 19/4 (2014), 271-286.

Shorey, Ryan C. vd.. "Dispositional Mindfulness, Spirituality, and Substance Usein Predicting Depressive Symptoms in a Treatment-Seeking Sample". Journal of Clinical Psychology 71/4 (2015), 334345. DOI:10.1002/iclp.22139

Siegel, Ronald D vd.. "Mindfulness: What is it? Where did it come from?" Clinical handbook of mindfulness. ed. F. Didonna. 17-35. Springer Science + Business, 2008. https://doi.org/10.1007/978-0387-09593-6_2

Strongman, Luke. "Pastoral Care and Mindfulness: A Teaching Practice". Journal of Education and Training Studies 5/3(2017), 118-122.

Sunar, Cavit. TasavvufFelsefesi veya Gerçek Felsefe. Ankara: Ankara Üniversitesi İlahiyat Fakültesi Yayınları, 1974.

Şahin, Meryem. Dini Bir Değer Olarak Tevekkül Yöneliminin Psikolojik Sebep ve Sonuçları Üzerine Araştırma. Bursa: Uludağ Üniversitesi, Sosyal Bilimler Enstitüsü, Doktora Tezi, 2018.

Şener, Mehmet. "Huşû". Türkiye Diyanet Vakfi İslâm Ansiklopedisi. Erişim 18 Eylül 2019. https://islamansiklopedisi.org.tr/husu

Tan, Seng Beng vd.. "Mindfulness: A New Paradigm of Psychosocial Care in the Palliative Care Setting in Southeast Asia". Ann Acad Med Singapore 46/9 (2017), 339-346.

Tenik, Ali - Göktaş, Vahit. “Tasavvufi Düşüncede Zikir ve Zikirin Benlik İş̧asına Etkisi”. Toplum Bilimleri 8/15 (2014), 263-286.

Thomas, Justin vd.. "The rise of mindfulness and its resonance with the Islamic tradition”. Mental Health, Religion \& Culture 20/10 (2018), 973-985 DOI:10.1080/13674676.2017.1412410

Tokur, Behlül. Kişisel Gelişim (NLP)-Din İlişkisi Üzerine Bir Araştırma. Erzurum: Atatürk Üniversitesi, Sosyal Bilimler Enstitüsü, Yüksek Lisans Tezi, 2006.

Tokur, Behlül. Stres-Dindarlk İlişkisi Üzerine Bir Araştırma. Erzurum: Atatürk Üniversitesi, Sosyal Bilimler Enstitüsü, Doktora Tezi, 2011.

Türkçapar, Hakan. Bilişsel Davranış̧̧ Terapi: Temelleri ve Ötesi. Epsilon Yayınevi, 2018.

Uludağ, Süleyman. “Gaflet”. Türkiye Diyanet Vakfi İslâm Ansiklopedisi. Erişim 18 Eylül 2019. https://islamansiklopedisi.org.tr/gaflet--tasavvuf

Uludağ, Süleyman. "Murakabe”. Türkiye Diyanet Vakfi İslâm Ansiklopedisi. Erişim 18 Eylül 2019. https://islamansiklopedisi.org.tr/murakabe

Uludă̆, Süleyman. “Tevekkül”. Türkiye Diyanet Vakfi İslâm Ansiklopedisi. Erişim 18 Eylül 2019. https://islamansiklopedisi.org.tr/tevekkul

Uludağ, Süleyman. “Tövbe”. Türkiye Diyanet Vakfi İslâm Ansiklopedisi. Erişim 18 Eylül 2019. https://islamansiklopedisi.org.tr/tovbe

Uludağ, Süleyman. "Müşahede". Türkiye Diyanet Vakfi İslâm Ansiklopedisi. Erişim 18 Eylül 2019. https://islamansiklopedisi.org.tr/musahede

Uludağ, Süleyman. "Murâkabe". Türkiye Diyanet Vakfi İslâm Ansiklopedisi. Erişim 18 Eylül 2019. https://islamansiklopedisi.org.tr/murakabe

Wong-Mc Donald, Ana - Gorsuch, Richard L.. "Surrender To God: An Additional Coping Style?". Journal of Psychology and Theology 28/2 (2000), 149-161.

Yavuz, Fatih K.. "Kabul ve Kararll1lk Terapisi (ACT): Genel Bir Bakış". Türkiye Klinikleri Dergisi Psikoterapinin Bugünü Özel Saylsl 8/2 (2015), 21-27.

Yavuz, Fatih K.. "ACT and Islam" ACT for Clergy and Pastoral Counselors: Using Acceptance and Commitment Therapy to Bridge Psychological and Spiritual Care, ed. Jason A. Nieuwsma vd.. 139-149. Oakland CA United States: New Harbinger Publications Inc., 2016. 